\title{
More THAN MeETS THE EYE: ReAsSessing THE EMPIRICAL EVIDENCE ON U.S. DUAL-CLASS STOCK
}

\author{
Bobby V. Reddy*
}

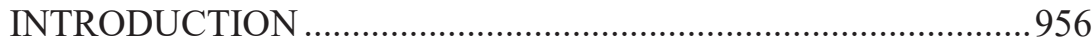

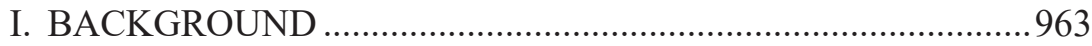

A. A Brief History of Time...................................................963

B. The Theoretical Detriments and Benefits of Dual-Class

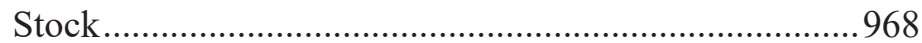

C. Where does the Balance Lie? .............................................973

II. THE EMPIRICAL EVIDENCE ON FIRM VALUE....................975

A. The Measure of Firm Value .............................................975

B. Firm Value Empirical Studies - the Results .....................977

C. Detailed analysis of Firm Valuation Studies..................... 977

D. Interpreting Firm Valuation Studies ................................982

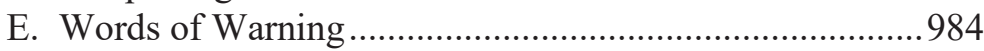

III. BUY-AND-HOLD STOCK RETURN STUDIES ......................987

A. Relevance of Buy-and-Hold Stock Return Studies..........987

B. Buy-and-Hold Stock Return Studies - the Results ...........988

C. Detailed Analysis of Buy-and-Hold Stock Return Studies

D. Interpreting Buy-and-Hold Stock Return Studies.............990

E. Words of Warning .............................................................993

IV. OPERATING PERFORMANCE STUDIES ..............................994

A. Operating Performance Measures ....................................994

B. Operating Performance Studies - the Results ..................994

C. Detailed Analysis of Operating Performance Studies......995

D. Interpreting Operating Performance Studies....................997

E. Words of Warning ...........................................................999

V. MAKING SENSE OF THE EMPIRICAL EVIDENCE ............ 1004

* Faculty of Law, University of Cambridge; Fellow, Churchill College, Cambridge; Fellow, Cambridge Endowment for Research in Finance. Former partner, Latham \& Watkins LLP. I thank Bernard Sharfman for his insightful comments. A summary of this article's findings was published on Columbia Law School's Blue Sky Blog on May 12, 2020. 


\title{
VI. FIRM AND CONTROLLER ATTRIBUTES AND THE IMPACT \\ ON PERFORMANCE MEASURE STUDIES ....................1006
}

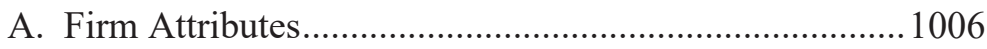

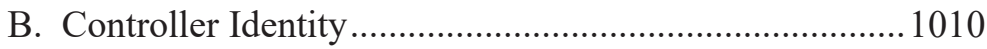

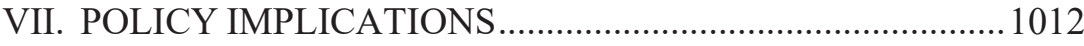

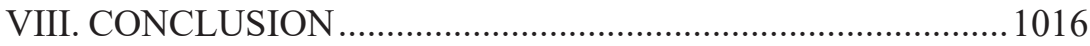

\begin{abstract}
Some of the largest and most successful publicly traded companies, such as Alphabet and Facebook, have implemented a capital structure known as dual-class stock. Dual-class stock enables a company's controller to retain voting control of a corporation while holding a disproportionately lower level of the corporation's cash-flow rights. Dualclass stock has led a tortured life in the U.S. and is perhaps the most controversial area of corporate governance today. Between institutional investor derision and the exclusion or restriction of dual-class stock from certain indices, one may assume that dual-class structure must be harmful to outside stockholders. However, in this article, the existing empirical evidence on U.S. dual-class stock will be reassessed by contrasting studies that use different measures of performance. It will be shown that although dual-class firms are generally valued less than similar one-share, one-vote firms, they perform as well as, and, in many cases, outperform, such firms from the perspective of operating performance and stock returns. When it comes to dual-class stock, more than meets the eye, and a presumption that dual-class stock is harmful for outside stockholders should not guide policy formulation.
\end{abstract}

\section{INTRODUCTION}

"More than meets the eye" was the famous tagline from the eighties robot toy and cartoon icons, the "Transformers." However, it is equally akin to the plethora of empirical evidence assessing the performance of listed companies that employ the capital structure known as "dual-class stock." This article will take a holistic view of the existing U.S. empirical evidence that is often used to attribute value or otherwise to such structures.

The term "dual-class stock" refers to a capital structure where a corporation issues different classes of stock to which are attached different

1. The Transformers, trademark Hasbro, Inc.; Transformers (Sunbow Productions and Marvel Productions Sept. 17 1984) 
levels of voting rights. ${ }^{2}$ Other than voting rights, the rights, including cashflow rights (rights to share in the profits of the company, through dividends and other distributions), attached to stock of each class are identical.

Accordingly, by retaining enhanced-voting stock, a controller can maintain majority voting control of a corporation while holding less than a majority of the cash-flow rights. The vast majority of U.S. listings subscribe to the more traditional capital structure of "one share, one vote" (OSOV), whereunder each share in the equity of the corporation has one vote. However, dual-class stock represents a growing minority of the U.S. listed company scene. Twenty-six percent of U.S.-IPOs adopted dual-class structure in the first half of $2019,{ }^{3}$ as compared to only one percent in 2005. ${ }^{4}$ Dual-class capitalization has been described as "the most important issue in corporate governance today", 5 and determining the sagacity of dual-class stock is an urgent mission for regulators, lawmakers, and exchanges in the U.S. and elsewhere.

A somewhat internecine battle has materialized between the institutional investor community, that has traditionally derided dual-class stock, ${ }^{6}$ and the cabal of management and founders, who have long advocated the merits of the structure. Institutional investors argue that dual-class stock merely entrenches control in the hands of managers with little personal stake in the interests of the company, exacerbating agency costs in a scenario where the investors have no power to remove the management team. Founders, however, argue that dual-class stock allows them to pursue their long-term visions, potentially for the benefit of all stockholders (and other stakeholders), without fear of being removed if

2. Although the term "dual-class stock" is commonly used, it refers to a capital structure where there exists multiple, not necessarily just two, classes of stock, each with varying voting rights attached as compared to their cash-flow rights. E.g., Alphabet, Inc. has unlisted shares with ten-votes-per-share, and two classes of publicly available stock, one of which has onevote-per-share, and one of which is non-voting (Amended and Restated Certificate of Incorporation of Alphabet Inc. dated October 2, 2015 at 2 and 10).

3. Council of Institutional Investors (CII), Dual-Class IPO Snapshot: 2017-2019 Statistic, https://www.cii.org/files/issues_and_advocacy/DualClassStock/2019\%20Dual\%20 Class\%20Update\%20for\%20Website\%20FINAL.pdf [https://perma.cc/T4DS-6BCP]. All URLs were last accessed on 1 March 2019, unless otherwise stated.

4. Spencer Feldman, Companies Opting to Go Public Offer Investors Class A One-VotePer-Share Stock, While Founders and Other Insiders Retain the Class B Super-Voting Shares for Themselves, 47 SRLR 1342, 1342 (2016).

5. John C. Coffee Jr., Dual Class Stock: The Shades of Sunset, CLS Blue Sky BloG (Nov. 19, 2018), http://clsbluesky.law.columbia.edu/2018/11/19/dual-class-stock-the-shadesof-sunset/ [https://perma.cc/5F4W-STNT].

6. E.g., CII, Dual-Class Stock, https://www.cii.org/dualclass_stock [https://perma.cc/ 34F2-8BS8]; Proxy Insight, An Interview with W. Robert Main III, Head of Portfolio Company Engagement, Analysis and Voting at Vanguard, Proxy Monthly 1, 4 (July 2017); Calpers Investment Committee, Dual Class/Non-Voting Shares Update 1, 9 (Apr. 2018). 
short-term metrics are not appealing to a short-term oriented stockholder base. The academic discourse has been no less fraught, generally split into two divergent camps. In the red corner, academics such as Bebchuk, Kastiel, Elson, and Ferrere have cast suspicion on the motives for, and consequences of, dual-class stock. ${ }^{7}$ In the blue corner, others such as Sharfman, Reddy, Winden, and Moore are more open to the benefits and opportunities that may be presented by dual-class stock, particularly if judicious constraints are formulated to ensure that the theoretical detriments are mitigated. ${ }^{8}$

Clearly, a tradeoff exists such that the merits of dual-class stock will depend upon which of the negative or positive aspects of the structure dominate. ${ }^{9}$ If dual-class stock has been implemented to enable a founder to pursue a long-term vision that generates large long-term profits, and, therefore, returns, during a period when the market is not able to observe the potential long-term benefits of the corporation's strategy, the structure could benefit all stockholders. However, if the principal purpose of the structure is to enable a management team to pursue personal interests to the detriment of the corporation, or to insulate a poor-quality management team that is unlikely to generate short- or long-term returns, the dual-class stock structure will likely be harmful to outside stockholders. Evidence as to whether, overall, in practice, dual-class stock firms are beneficial or detrimental to outside stockholders could be deduced by assessing the performance of such firms as compared to OSOV firms. The evaluation of the empirical evidence has not, though, been simple or conclusive, and the evidence has often been interpreted to substantiate preconceived ideological viewpoints. In particular, much conjecture has surrounded the

7. E.g., Lucian Bebchuk \& Kobi Kastiel, The Untenable Case for Perpetual Dual-Class Stock, 4 VA. L. ReV. 585 (2017); Lucian Bebchuk \& Kobi Kastiel, The Perils of SmallMinority Controllers, 107 GEO. L. J. 1453 (2019); Charles Elson \& Craig Ferrere, Unequal Voting and the Business Judgment Rule, HARV. LAw SCH. FORUM ON CORP. GOVERnANCE \& Fin. Regulation (Apr. 7, 2018).

8. E.g., Bernard S. Sharfman, A Private Ordering Defense of a Company's Right to Use Dual Class Share Structures in IPOs, 63 Villanova L. REV. 1 (2018); Bernard S. Sharfman, The Undesirability of Mandatory Time-Based Sunsets in Dual Class Share Structures: A Reply to Bebchuk and Kastiel 93 S. CALIF. L. ReV. Postscript 1 (2019); Bobby V. Reddy, Finding the British Google: Relaxing the Premium-Tier Prohibition of Dual-Class Stock, 79 CAmBridge L.J. 315 (2020); Andrew Winden, Sunrise, Sunset: An Empirical and Theoretical Assessment of Dual-Class Stock Structures, 3 CBLR 852 (2018); Marc Moore, Designing Dual Class Sunsets: The Case for a Transfer-Centered Approach 12 WM. \& MARY BuS. L. REV. 93 (2020).

9. Ronald Gilson and Jeffrey Gordon, Controlling Controlling Shareholders, 152 U. PA. L. REV. 785 (2003) first developed the concept of a "tradeoff" in the context of controlling shareholders generally. However, the concept, with variations to account for the divergence between voting and cash-flow rights, can be extended to the ambit of dual-class structure. 
assessment of empirical evidence that attempts to correlate dual-class structure with firm value based upon some derivation of the ratio of the market capitalization of the corporation to the book value of its assets. ${ }^{10}$ Some have interpreted the firm value data to corroborate that dual-class structure is detrimental to outside stockholder interests. ${ }^{11}$ In contrast, others have suggested that the empirical evidence of this nature is inconclusive, and, therefore, that dual-class structure is beneficial to some types of firms and detrimental to others. ${ }^{12}$ To the other extreme, some commentators have noted more recent empirical evidence indicating that dual-class stock enhances firm value, and therefore the possibility that the benefits of the structure outweigh the drawbacks. ${ }^{13}$ In this article, a more holistic view of the available evidence will be taken, by not just focusing on the correlation between firm value and dual-class structure, but by also comparing other studies that evaluate other metrics of firm performance.

Firm value results can be easily misinterpreted. One of the traditional interpretations offered for low firm value, where that measure is based upon the divergence between market capitalization and asset value, is that it is indicative of poor management. ${ }^{14}$ Since, in an efficient market, ${ }^{15}$ share price will reflect future profitability, which will differ from the value of the firm's assets, essentially, the market is discounting the value of the corporation's future cash-flow or earnings growth. Accordingly, in the context of dual-class stock, if a dual-class corporation is valued less than an equivalent OSOV corporation, a natural assumption is that the firm is being managed poorly where neither the stockholders nor the market has the power to change that management team. Poor management in these

10. One such derivative, “Tobin's Q", is the most commonly used measure of firm value in such studies. For a description and discussion of Tobin's Q, see infra Part II.

11. E.g., Bebchuk \& Kastiel (2019), supra note 7, at 1471.

12. E.g., Renée Adams and Daniel Ferreira, One Share-One Vote: The Empirical Evidence, 12 Rev. Fin. 51, 65 (2008); Anita Anand, Governance Complexities in Firms with Dual Class Shares, 3 AnNAL. Corp. Gov. 184, 203 (2018).

13. E.g., Yvan Allaire, The Case for Dual-Class of Shares, Inst. For Governance OF Private and Pub. Orgs. Policy PAPer 11, 1, 41 and 55 (2019). The authors did note, however, that taking recent and older studies as a whole painted a more inconclusive picture. Id. at 36 .

14. Randall Morck et al, Management Ownership and Market Valuation, 20 J. Fin. ECON. 293 (1988)

15. An efficient market is one where all public information is quickly incorporated into the price of securities. Eugene Fama, Efficient Capital Markets: A Review of Theory and Empirical Work, 25 J. FIN. 383, 383 (1970). More nuanced versions of the Efficient Capital Markets Hypothesis (ECMH) have subsequently been developed - the weak form (where all information from past share prices is incorporated), the semi-strong form (where all public information is incorporated), and the strong form (where public and non-public information is incorporated). For a discussion on the forms of ECMH, see BRIAN CHEFFINS, COMPANY LAW: TheOry, Structure AND Operation, at 56 (1997). 
circumstances not only encompasses underperformance from the perspective of a lack of talent or diligence, but also underperformance due to the controller of the corporation causing the corporation to pursue the personal interests of the controller to the detriment of the corporation's interests. $^{16}$

However, it is not unequivocal that the market is perfectly efficient, and that low firm values are obviously representative of the potential detriments of dual-class firms dominating over the benefits. Instead, the market may be systemically discounting dual-class corporations in anticipation of future poor performance that does not actually emerge. The premise will be tested by assessing two further measures of firm performance, the first of which relates to buy-and-hold stock returns. In such a study, a notional portfolio of dual-class firm listed stock is compared to a notional portfolio of matched OSOV firm listed stock, over an extended period of time. If all information relevant to predicted future performance is being efficiently assimilated by the market, stock returns over extended periods of time should be similar for dual-class and OSOV corporations. To the extent that the market ascertains that dual-class corporations will underperform (overperform) OSOV corporations, they will be valued lower (higher) than OSOV corporations, such that the overall returns on investment remain comparable. In such a case, from the perspective of outside investors, the implementation of dual-class stock or OSOV is irrelevant to their interests, since they organically protect themselves by ensuring that the relevant firms are, on average, priced so that they receive similar returns no matter the capital structure. If, on the other hand, buy-and-hold stock return studies show that investors in dualclass stock corporations receive higher (lower) stock returns than OSOV corporations, it could indicate that dual-class firms are being regularly under (over) valued.

The second further type of firm performance study reviewed appraises the relative operating performance of dual-class firms. The studies utilize a variety of accounting measures, mainly related to profitability, to ascertain whether dual-class firms perform better or worse than OSOV firms. If dual-class firm management underperforms OSOV firm management, one may expect to find that the operating performances of dual-class firms are worse than those of OSOV firms. By comparing the empirical trends from firm value, buy-and-hold stock return, and operating performance studies,

16. Such behavior is often described as the pursuit of "private benefits of control". The controller can use its control of the corporation to cause it to take actions that are personally beneficial to the controller. As such, private benefits of control also apply in OSOV controlling shareholder scenarios, but as will be discussed further in this article, the incentives to extract such private benefits are amplified where the controller holds a disproportionately lower level of cash-flow rights as can be the case with dual-class stock structures. 
a more absolute view can be formed as to whether dual-class firms are, in the real-world, beneficial or injurious to the interests of outside stockholders.

It will be shown in this article that firm valuation studies generally show dual-class corporations to be correlated with lower valuations than OSOV corporations. Although the customary ensuing interpretation is that dual-class firms are associated with entrenched managers that are performing poorly and possibly expropriating outside stockholders by prioritizing personal interests (as controlling stockholders) over stock value, it will also be shown that the majority of buy-and-hold stock return studies show notional portfolios of dual-class firms to generate higher returns than portfolios of matched OSOV firms. This would suggest that dual-class firms are being undervalued. Outside investors are overestimating the risks presented by dual-class firms; the resulting undervaluations result in the stock prices of dual-class corporations increasing at a greater rate than matched OSOV corporations, ascribing greater returns to investors.

The results of operating performance studies give further color as to why portfolios of dual-class firms seemingly result in larger buy-and-hold returns than portfolios of similar OSOV firms. Several operating performance studies indicate that dual-class corporations display greater operating performance fundamentals over time than matched OSOV corporations, and no such studies have shown them, on the whole, to perform worse than OSOV firms. The management teams of dual-class corporations are not less proficient at leading those firms compared to similar OSOV corporations, and, in fact, potentially operate those firms more profitability than their OSOV brethren. The results of operating performance studies resonate with the capacity for dual-class structure to enable founders to manage their companies with a long-term focus, without being beholden to short-term market influences that could encumber the true long-term potential of the company, and create greater profitability for all stockholders over time. ${ }^{17}$ Taking all three types of empirical evidence

17. Whether the equity markets are indeed short-term oriented is a matter of contention, with some asserting the short-termism of institutional investors. E.g., ANDREI SHLEIFER, INEFFICIENT MARKETS: AN INTRODUCTION TO BEHAVIOURAL FINANCE, (2000); Ronald Gilson \& Reinier Kraakman, The Mechanisms of Market Efficiency Twenty Years Later: The Hindsight Bias, Harv. L. School Discussion PAPer No 446 1, 14 (2003); Richard Davies et al, Measuring the Costs of Short-Termism, 12 J. FIN. STAB. 16, 20 (2014). Others note that the concerns may be overstated. E.g., Brian Bushee, The Influence of Institutional Investors on Myopic R\&D Investment Behavior, 73 ACCOUNT. REV. 305, 322 (1998); Jeffrey Abarbanell \& Victor Bernard, Is the US Stock Market Myopic, 38 J. AcCounT. RES. 221 (2000); Lucian Bebchuk et al, The Long-Term Effects of Hedge Fund Activism, 115 CoLum. L. REv. 1085, 
together, the most plausible interpretation is that the market is not efficient, and the market is ideologically predisposed to discount dual-class stock investors wish to protect themselves from the risk that the potential detriments associated with dual-class structure will dominate over the potential benefits, even though the empirical evidence suggests that, on average, those risks do not play out in practice. The better operating performance of dual-class firms is so stark that investors can earn greater returns from portfolios of such stock, as compared to portfolios of similar OSOV stock, even though the market perpetually undervalues the stock.

The policy implications are twofold. Firstly, the equity market organically protects itself from the potential for dual-class corporations to harm outside investors by discounting the price at which the stock of such companies will be purchased. As such, outside investors in such companies do not earn less returns than they would have done had they invested in similar OSOV companies. Therefore, policy-makers should be cautious in succumbing to pressure to impose deterrents on the listing of dual-class corporations on the basis that they are harmful to outside stockholders. Second, the discounts applied to dual-class corporations are not justified by the evidence pertaining to their subsequent operating performances. Accordingly, the cost of capital for dual-class issuers is higher than can be warranted by the risks accruing to outside investors. Policy-makers should pivot from considerations as to whether dual-class listings should be deterred, to considerations as to how the cost of capital for dual-class issuers can be lowered.

Part I of this article will set out the background to the subsequent analysis, outlining a brief history of dual-class stock in the U.S. to the present-day obsession in the tech-sphere, the theoretical benefits and detriments of the structure to outside stockholders, and the importance of the empirical evidence in ascertaining how the balance between positive and negative qualities plays out in practice. Part II will evaluate the U.S. empirical studies that seek a correlation between dual-class structure and firm value. Part III will assess the handful of studies that compare the buyand-hold market returns of portfolios of U.S. dual-class corporations to

1141 (2015); Lucian Bebchuk, The Myth that Insulating Boards Serves Long-Term Value, HARV. DisCUSSION PAPER No. 755 1, 29 et seq (2013). However, even the perception that the market is short-term oriented can have a deleterious impact on management decision-making where, with OSOV, the managers are not insulated from the stockholders and the market for corporate control. Michael Jensen, Agency Costs of Overvalued Equity, Fin. Mgmt. 5, 6 (2005); James Ang \& William Megginson, Restricted Voting Shares, Ownership Structure, and the Market Value of Dual-Class Firms, 12 J. FIn. Res. 301, 305 (1989); Adam Brandenburger \& Ben Polak, When Managers Cover Their Posteriors: Making the Decisions the Market Wants to See, 27 Rand J. ECON. 523 (1996); Natalie Mizik, The Theory and Practice of Myopic Management, 47 J. MARK. RES. 594, 594 (2010). 
those of OSOV corporations. Part IV describes the output from U.S. studies that examine the correlation between dual-class structure and operating performance. Part V will develop a coherent interpretation of the holistic evidence. In Part VI, this article will, based upon the existing empirical evidence, broach the prospect that the type and attributes of a firm and its controller may influence how such a firm performs across all performance measures. Finally, policy implications will be presented in Part VII, before the conclusion.

As far as this author is aware, this is the first article to collate existing empirical studies on dual-class firms that use different performance measures with a view to reconciling the findings into a coherent whole. Although certain individual empirical studies have tested dual-class corporations across more than one performance measure, ${ }^{18}$ this article pulls together the results from multiple empirical sources. Other studies have aggregated and summarized the existing empirical evidence on dual-class firms, but they have mainly centered on critically scrutinizing the statistical approaches utilized, ${ }^{19}$ or have focused on the inconclusiveness stemming from different performance measures without explaining the possible significance. ${ }^{20}$ This article contributes to the existing literature by rationalizing the divergences between the findings of different performance measure studies, resulting in an original interpretation of the real-world merits of dual-class firms. Policy-making in this field has often been led by a perception that dual-class stock is harmful to outside stockholders, but by going against the grain of conventional opinion, this article will show that outside stockholders are not, on average, harmed by investing in dualclass stock. Empirical evidence on dual-class stock must be carefully interpreted in a comprehensive manner to accurately inform policy considerations. This article provides a novel contribution to that debate and the policy implications are outlined further herein.

\section{BACKGROUND}

\section{A. A Brief History of Time}

It should be noted that dual-class stock is not a new development. ${ }^{21}$ The structure attracted much infamy in the 1920s after two high-profile

18. See infra notes 214 and 218-219, and accompanying text.

19. E.g., Adams \& Ferreira, supra note 12.

20. E.g., Anand, supra note 12.

21. The first known instance of a U.S.-listed corporation issuing true dual-class stock was when International Silver Company issued non-voting stock in 1898. Jason Howell, The Survival of the U.S. Dual Class Share Structure, 44 J. CORP. Fin. 440, 444 (2017). 
New York Stock Exchange (NYSE) IPOs where the controllers of Dodge Brothers, Inc. ${ }^{22}$ and Industrial Rayon Corporation ${ }^{23}$ retained control through the holding of voting stock, while issuing non-voting stock to the public. ${ }^{24}$ Soon after, the NYSE effectively prohibited dual-class stock from its exchange. $^{25}$ The status quo was maintained until the 1980s when the NYSE relaxed its prescription of OSOV. The NYSE's change of tact was precipitated by one of its blue-chip issuers, General Motors, in 1984, flouting the prohibition of dual-class stock by issuing stock with disproportionately lower voting rights compared to equity rights to the sellers upon its acquisition of Electronic Data Systems Corporation. ${ }^{26}$ Rather than de-listing the listed behemoth, the NYSE, instead, declared a moratorium on enforcement against the issuers of dual-class stock. ${ }^{27}$ In the midst of a burgeoning hostile takeover environment, many issuers wasted no time in recapitalizing their capital structures into dual-class stock, as a means of takeover defense, so that managers and other insiders could maintain sufficient voting control to block takeovers even though outsiders were providing the majority of the equity capital. ${ }^{28}$ In the face of pressure

22. Joel Seligman, Equal Protection in Shareholder Voting Rights: The One Common Share, One Vote Controversy, 54 Geo. WASH. L. REV. 687, 694 and 700 (1985-1986); Philip Loomis \& Beverly Rubman, Corporate Governance in Historical Perspective, 8 Hofstra L. REV. 141, 152 (1979); Manning Warren III, One Share, One Vote: A Perception of Legitimacy, 14 J. CORP. L. 89, 92 (1988).

23. Seligman, supra note 22, at 694.

24. Both IPOs generated substantial adverse publicity after criticism amongst the academic community. E.g., William Ripley, Two Changes in the Nature and Conduct of Corporations, 11 Proc. ACAD. Pol. Sci. 695, 696 (1926); Adolf Berle, Non-Voting Stock and “Bankers' Control”, 39 HaRv. L. Rev. 673, 676 (1926); William Ripley, MAin STREeT AND WALL STREET, at 77 (1927).

25. The NYSE informally prohibited dual-class stock in 1926. Seligman, supra note 22, at 697; Loomis \& Rubman, supra note 22, at 152; Timothy O'Neil, Rule 19c-4: The SEC Goes Too Far in Adopting a One Share, One Vote Rule, 83 NW. U. L. REv. 1057, 1064 (1989); Douglas Ashton, Revisiting Dual-Class Stock, 68 ST. JoHN’s L. REV. 863, 893 (1994). It followed this up with a formal prohibition, pursuant to a Statement of Listing Principles, published in 1940. Seligman, supra note 22, at 699.

26. O'Neil, supra note 25, at 1064; Ashton, supra note 25, at 894; Warren III, supra note 22 , at 93 .

27. Warren III, supra note 22, at 93.

28. The mid-1980s saw a rash of hostile takeover activity. Jeffrey Gordon, Ties that Bond: Dual Class Common Stock and the Problem of Shareholder Choice, 76 CAL. L. Rev. 1, 4 (1988); Wolf-Georg Ringe, Deviations from Ownership-Control Proportionality Economic Protectionism Revisited in COMPANy LaW and ECONOMic ProteCtionism: New Challenges to European Integration 209, 225 (Ulf Bernitz and Wolf-Georg. Ringe eds., 2010; Matthew Cain et al, Do Takeover Laws Matter? Evidence From Five Decades of Hostile Takeovers, 124 J. FIN. ECON. (2017) 464, 468. In response, in a three-year period ended June 1987, on the back of the NYSE's moratorium on delisting dual-class structures, 
from managers, who held a great degree of sway in the listed company sphere at the time, ${ }^{29}$ and competition from other exchanges such as AMEX and NASDAQ ${ }^{30}$ a subcommittee of the NYSE recommended a formal acceptance of dual-class stock. ${ }^{31}$ In an ill-fated attempt to pre-empt the NYSE's desire to formally relax its prohibition on dual-class stock, the Securities and Exchange Commission (SEC) introduced Rule 19c- $4,{ }^{32}$ which would have required U.S. exchanges to delist any corporation that "issues any class of security, or takes other corporate action, with the effect of nullifying, restricting or disparately reducing the per share voting rights of holders of an outstanding class or classes of common stock of such issuer." 33 Although the SEC's stance has sometimes been described as an attempt to mandate OSOV, in fact, Rule 19c-4 did not prohibit the exchanges from permitting the IPOs of companies implementing dual-class stock $a b$ initio. Even mid-stream recapitalizations would have been permitted so long as existing stock was not disenfranchised. In any case, Rule 19c-4 was eventually struck down by the Court of Appeals for the District of Columbia after being challenged by a representative

more than 46 NYSE corporations either issued inferior-voting shares or restricted the voting power of large shareholders. Warren III, supra note 22, at 93.

29. Although the holdings of institutional investors were rising dramatically, they did not, at that time, account for a majority of equity holdings on the NYSE. Institutional stockholders held, on average, twenty-four percent of a NYSE firm's equity in 1980, rising to forty-four percent in 2000. Richard Sias et al., Changes in Institutional Ownership and Stock Returns: Assessment and Methodology, 79 J. Bus. 2869, 2877 (2006).

30. NASDAQ and AMEX (except for a prohibition on pure non-voting stock that had applied since 1972) had not implemented restrictions on dual-class stock. See Warren III, supra note 22, at 92 (noting the lack of prohibition on listing common stock with disparate voting power); see also Ronald Gilson, Evaluating Dual Class Common Stock: The Relevance of Substitutes, 73 VA. L. REV. 807, 807 (1987) (summarizing the less stringent voting standards of NASDAQ and AMEX).

31. Certain restrictions on dual-class stock were, though, recommended by the subcommittee, including that the structure must be approved by two-thirds of all stockholders, implement a maximum voting ratio of 10:1, and provide that, other than voting rights, all classes of common stock have equivalent rights attached. Warren III, supra note 22, at 94. The NYSE eventually rejected those restrictions and simply determined that any dual-class stock outstanding at the time of a corporation's IPO should be permitted to list. However, any stock issued at a later date, or created by way of the modification of existing stockholder rights, would need to be approved by a majority of independent directors and public stockholders, and the prohibition of pure non-voting stock would remain in place. Gilson, supra note 30, at 807; see also Warren III, supra note 22, at 93 (outlining the proposed 1986 NYSE amendments and circumstances surrounding them); Ashton, supra note 25, at 898 (same).

32. 17 C.F.R. 5 \& 240.19c-4 (1934) (governing certain listing or authorization determinations by national securities exchanges and associations). The short-lived Rule 19c4 was promulgated by the SEC and adopted in 1988 under Section 19(c) of the 1934 Act.

33. Id. $\S 240.19 \mathrm{c}-4(\mathrm{a})$. 
organization for large publicly-listed corporations, the "Business

Roundtable." ${ }^{\prime 34}$ It was held that the SEC had exceeded the powers that had been imbued by Congress. ${ }^{35}$ Eventually, though, to a large degree, the NYSE's formal acquiescence of dual-class stock structures emulated Rule $19 \mathrm{c}-4$, permitting dual-class stock on the exchange but prohibiting corporate actions that disparately reduce the voting rights of existing publicly traded stock. ${ }^{36}$

After the initial spate of dual-class recapitalizations in the 1980s, the number of firms either recapitalizing from OSOV to dual-class stock or engaging in a dual-class stock IPO broadly stabilized until 2004. ${ }^{37} 2004$ was the year of Google, Inc.'s (Google) seminal dual-class stock IPO. ${ }^{38}$ The founders, Larry Page and Sergey Brin, redesignated a portion of their stock as Class B stock with ten-votes-per-share, and listed Class A OSOV shares on NASDAQ. ${ }^{39}$ Only Class A OSOV shares were available to the public, leaving a majority of the voting rights, but a minority of the cashflow rights, in the hands of the founders. In many respects, Google's capital structure was a trailblazer for the technology industry. Buoyed by Google's success, ${ }^{40}$ as shown in Figure 1, the proportion of "large" ${ }^{41}$ U.S.

34. Business Roundtable v. SEC, 905 F.2d 406 (D.C. Cir. 1990).

35. See id. at 417 (vacating Rule 19c-4 after finding that the SEC relied on insufficient statutory authority to promulgate the regulation).

36. The current version of the NYSE Listed Company Manual $\S 313.00(A)$ (2018) states: Voting rights of existing shareholders of publicly traded common stock... cannot be disparately reduced or restricted through any corporate action or issuance. Examples of such corporate action or issuance include, but are not limited to, the adoption of time phased voting plans, the adoption of capped voting rights plans, the issuance of super voting stock, or the issuance of stock with voting rights less than the per share voting rights of the existing common stock through an exchange offer.

37. See J. Ritter, Initial Public Offerings: Dual Class Structure of IPOs Through 2020 (updated Dec. 28, 2020), https://site.warrington.ufl.edu/ritter/files/2020/02/IPOs2019DualC lass.pdf [https://perma.cc/QP32-6YLR] (tabulating the number of IPOs each year with dual class shares among both tech IPOs and non-tech IPOs); Valentin Dimitrov \& Prem C. Jain, Recapitalization of One Class of Common Stock Into Dual-Class: Growth and Long-Run Stock Returns, 12 J. CORP. FIN. 342, 348 (2006) (tabulating dual-class announcements by year and exchange). 2002 was an outlier year, during which $21.2 \%$ of "large" IPOs involved dualclass stock; however, that year was a fallow year for IPOs generally, with only sixty-six IPOs taking place. Ritter, supra.

38. After a restructuring on October 2, 2015, Alphabet, Inc. became the new listed holding company of Google. Hereinafter, throughout this article, "Google" shall refer to both the original listed company, Google, Inc., and the new holding company Alphabet, Inc.

39. In April 2014, Google further split its Class A stock into Class A and non-voting Class C stock, allowing Google to issue further stock without diluting the insiders' control of the corporation. See supra note 2.

40. See infra note 70 .

41. AMEX, NYSE, and NASDAQ IPOs with an offer price of at least \$5.00. Ritter, supra note 37 . 
tech-corporation IPOs employing dual-class stock surged. In a repeat of history, reflecting the pre-NYSE prohibition of dual-class stock in the 1920 s, the U.S. exchanges are seeing a plethora of firms employing dualclass stock as of IPO, rather than the mid-1980s trend for existing issuers to recapitalize from OSOV into dual-class stock to resist hostile takeover activity. ${ }^{42}$ After 2004 many tech-company household names, such as Facebook, Inc., LinkedIn Corporation, and Groupon, Inc., ${ }^{43}$ adopted IPO dual-class structures. This vogue has continued in recent years, and in 2019 alone, Slack Technologies, Inc., Lyft, Inc. (Lyft), and Pinterest, Inc. (Pinterest), listed with dual-class stock. . ${ }^{44}$

42. See Dimitrov \& Jain, supra note 37 , at 348 (reporting the distribution of dual-class announcements by year and exchange using a sample of 178 firms).

43. Upon listing, both Facebook and LinkedIn (which was subsequently taken private by Microsoft Corporation in 2016) issued OSOV-shares to the public, while insiders retained shares with ten-votes-per-share. Facebook Inc, Registration Statement (Form S-1), at 8 (Feb. 1, 2012); LinkedIn Corp., Amendment No. 5 To Form S-1 Registration Statement (Form S1/A), at 26 (May 17, 2011). The founders of Groupon retained shares with 150-votes-pershare and issued OSOV-shares to the public. Groupon Inc., Amendment No. 7 To Form S-1 Registration Statement (Form S-1/A), at 134 (Nov. 1, 2012). Upon the operation of a timedependent sunset clause, Groupon's dual-class structure was subsequently unified into OSOV in 2016. Council Inst. Invs., Companies with Time-Based SunSET Approaches to DuAlClass Stock, (Feb. 13, 2019), https://www.cii.org/files/2-13-19 Time-based Sunsets.pdf [https://perma.cc/R5DU-7L6P] (tabulating companies with provisions where, at a fixed point in time, the class of shares with enhanced-voting rights converts into common stock with one vote per share automatically); see infra note 259 and accompanying text.

44. Both Lyft and Pinterest implemented a 20:1 voting ratio, and Slack Technologies a 10:1 voting ratio, between enhanced-voting and inferior-voting shares. Lyft Inc., Registration Statement (Form S-1), at 194 (Mar. 1, 2019); Pinterest Inc., Registration Statement (Form S1), at 163 (Mar. 22, 2019); Slack Techs. Inc., Registration Statement (Form S-1), at 154 (Apr. 26, 2019). 


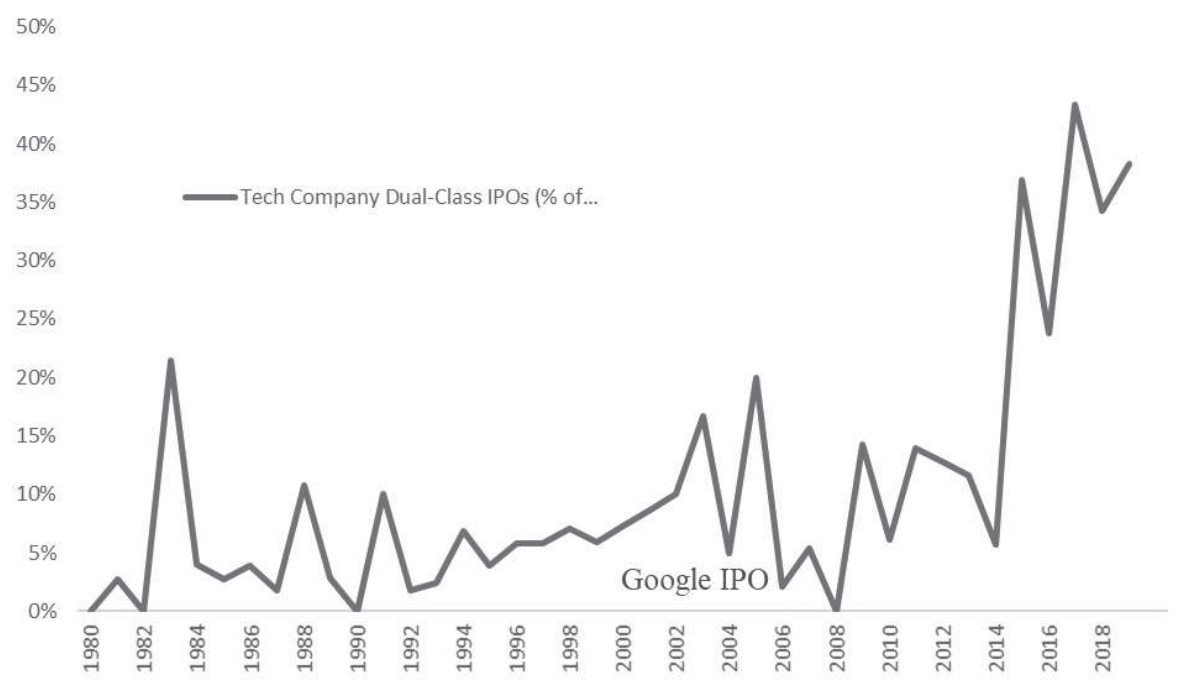

FIGURE 1 - "LARGE" (SUPRA NOTE 41) U.S. DUAL-CLASS TECH-IPOS AS A PERCENTAGE OF TOTAL TECH-IPOS. DATA DERIVED FROM: RITTER (SUPRA NOTE 37)

\section{B. The Theoretical Detriments and Benefits of Dual-Class Stock}

The controversy that has followed dual-class stock over the decades stems from the potential for it to enable a separation between voting and cash-flow rights in the hands of a shareholder. By way of example, at Google, as of December 31, 2018, the two founders owned fifty-one percent of the voting rights of the company, but only $11.3 \%$ of the cashflow rights. ${ }^{45}$ Consequentially, dual-class firms present somewhat of an enigma, since that very separation between voting and cash-flow rights can lead to positive and negative outcomes. Those positive and negative outcomes can vary in line with the ownership profile of the dual-stock corporation. However, in the U.S., overwhelmingly, the holders of enhanced-voting stock are individuals, ${ }^{46}$ and majority (or at least effective)

45. Data derived from: Alphabet Inc., Schedule 13G/A (Feb. 12, 2018) (filed by Larry Page); Alphabet Inc., Schedule 13G/A (Feb. 14, 2019) (filed by Sergey Brin); Alphabet Inc., Statement of Changes in Beneficial Ownership (Form 4) (Dec. 3, 2018) (filed by Sergey Brin); Alphabet Inc., Annual Statement of Changes in Beneficial Ownership (Form 5) (Feb. 8, 2018); Alphabet Inc., Notice of 2018 Annual Meeting of Stockholders and Proxy Statement (Form DEF 14A) (Apr. 27, 2018).

46. Ronald Anderson et al., The Dual Class Premium: A Family Affair, 1, 2 (Fox Sch. Bus., Research Paper No. 17-021, 2017) examined Russell 3000 dual-class firms listed as of 
voting control is almost inevitably held by a single or related group of enhanced-voting stockholders. ${ }^{47}$ The controller or controllers are also usually part of the management team. ${ }^{48}$ Correspondingly, for the purposes of the interpretations outlined in this article, unless otherwise specified, it will be assumed that the relevant dual-class firm is controlled by a controller or related controllers, involved in management, holding disproportionately fewer cash-flow rights through the holding of enhancedvoting stock.

From a negative perspective, a shareholder with sufficient voting control can cause the corporation to take actions that are personally beneficial to the shareholder-known in the literature as "private benefits of control"- - but detrimental to the interests of the corporation and the other shareholders. To the extent that the actions are detrimental to share value, the controlling shareholder only suffers to the extent of its equity interest but receives one hundred percent of the private benefits. Such behavior can, of course, transpire in an OSOV corporation where a shareholder holds a controlling, but less than one hundred percent, interest. ${ }^{49}$ However, with dual-class stock, the controller can considerably reduce its exposure to the equity value of the firm to well below fifty percent, while continuing to retain control. Accordingly, the incentive to extract private benefits of control increases as the level of cash-flow rights

2001 and found that only eleven percent were not family/founder-controlled. In BEN Amoako-Adu et Al., Dual Class Discount, and the Channels of Extraction of Private Benefits, in AdVANCES In FinANCIAL ECONOMics 165, 185 (2013), the dual-class firm sample (2001-2007) consisted of 83.21\% family-controlled firms.

47. Bebchuk \& Kastiel (2019), supra note 7, at 1496, found that 83.6\% of Russell-3000 dual-class companies have a controlling minority shareholder (an earlier draft noted the figure as $96.7 \%$ of S\&P-1500 dual-class firms).

48. Rafael La Porta et al., Corporate Ownership Around the World, 54 J. Fin. 471, 500 (1999) showed that sixty-nine percent of large companies in wealth economies that are controlled by individuals or families also have board representation by such controllers at CEO or chair level. More recently, in a random sample of 375 U.S.-listed firms, in cases where the largest blockholder was an individual, a named representative served on the board in ninety-one percent of the cases, and sixty-two percent of individual blockholders were both directors and officers. Alex Edmans \& Clifford G. Holderness, Blockholders: A Survey of Theory and Evidence, in THE HandBook of the ECONOMics of CORPORATE Governance 541, 553 (Benjamin E. Hermalin \& Michael S. Wesibach eds., 2017). From a sample of 241 firms with dual-class structure between 1999 and 2000, in only seven percent of the cases was the controller outside of the management team. Chun-Keung Hoi \& Ashok Robin, Agency Conflicts, Controlling Owner Proximity, and Firm Value: An Analysis of Dual-Class Firms in the United States, 18 CORP. GOVERnANCE 124, 128 (2010).

49. See, e.g., Bobby V. Reddy, The Fat Controller: Slimming Down the Excesses of Controlling Shareholders in UK Listed Companies, 38 Oxford J. LEGAL STUD. 733, 735-38 (2018) (using Sports Direct as an example to explain how controlling shareholders can extract private benefits). 
held by the controller decreases. The incentive to extract private benefits of control can manifest itself in a variety of controller actions, including causing the corporation to enter into conflicted transactions or transactions that are personally beneficial to the controller but not necessarily the optimum choice for the corporation, extracting a control premium upon a takeover which is not made available to the non-controlling shareholders, and even simply stealing the corporation's assets and profits. Furthermore, since the market for corporate control ${ }^{50}$ is eroded in the presence of a controlling shareholder who also manages the corporation, the interests of outside stockholders could be prejudiced by poor and underperforming management. Such management will not be exposed to potential replacement and, with the controller holding only a small portion of the equity, the controller will not be overly concerned about the negative impact on share price caused by such underperformance. Private benefits of control may not just be financial in nature, but can also encompass nonpecuniary benefits, such as reputation, prestige, or political capital. ${ }^{51} \mathrm{~A}$ controller may sacrifice firm value to pursue such non-pecuniary private benefits. $^{52}$

Conversely, a dual-class stock structure can encourage and enable positive corporate behaviors that can be beneficial to outside stockholders. The management team, insulated from the market for corporate control, can make decisions and take actions that will create long-term benefits for the company, even if they result in short-term share price declines. ${ }^{53}$ Although,

50. In relation to the potential for the market for corporate control to discipline managers, see generally Henry G. Manne, Mergers and the Market for Corporate Control, 73 J. POL. ECON. 110 (1965) (an introduction to a study of the market for corporation control).

51. See Philippe Aghion \& Patrick Bolton, An Incomplete Contracts Approach to Financial Contracting, 59 REV. ECON. STUD. 473, 476 (1992) (analyzing the non-monetary, less tangible motivations of entrepreneurs, including reputation and specific human capital); Alexander Dyck \& Luigi Zingales, Private Benefits of Control: An International Comparison, 59 J. FIN. 537, 542 (2004) (other private benefits include the psychic value related to being in control); see also Ronald J. Gilson, Controlling Shareholders and Corporate Governance: Complicating the Comparative Taxonomy, 119 HARV. L. REV. 1641, 1664 (2006) (distinguishing between pecuniary and non-pecuniary private benefits of control).

52. Paul A. Gompers et al., Extreme Governance: An Analysis of Dual-Class Firms in the United States, 23 REV. FIN. STUD. 1051, 1085 (2010) (concluding that a majority owner of a private company may sacrifice some pecuniary value to maintain control over other domains, including editorial policy, corporate strategy, or brand identity).

53. See Daniel R. Fischel, Organized Exchanges and the Regulation of Dual Class Common Stock, 54 U. CHI. L. REV. 119, 139 (1987) (noting that investors whose wealth is not tied up in their firm can diversify risk more efficiently); Harry DeAngelo \& Linda DeAngelo, Managerial Ownership of Voting Rights, A Study of Public Corporations with Dual Classes of Common Stock, 14 J. FIN. ECON. 33, 35 (1985) (noting that vote ownership can encourage managers to invest in organization-specific capital); Zohar Goshen \& Assaf Hamdani, 
in an efficient market, ${ }^{54}$ share price should reflect the long-term prospects of the company, much skepticism has been directed at the efficiency of the equity capital markets. ${ }^{55}$ For instance, the nature of the assets and projects of the relevant business may render the long-term benefits of actions unobservable to outsiders. Furthermore, studies have also suggested that the equity markets display a short-term bias. ${ }^{56}$ For a company for which taking a long-term approach is crucial, dual-class stock provides management with the required breathing space when short-term profits are not prolific. It is therefore of no coincidence that high-growth tech-firms have recently adopted dual-class structure in droves, being, as they are, reliant on large levels of research and development spending. ${ }^{57}$ Productcycles can also be long and not easily observable by outside investors, with asymmetric information issues applying where confidentiality and commercial sensitivity are at a premium. ${ }^{58}$ Dual-class structure enables a tech-company founder to cause the corporation to make those long-term investments without trepidation that the market for corporate control could curtail its long-term vision, whilst also enabling it to divest of a substantial proportion of its investment in the corporation and grow the corporation through equity funding. Moreover, debt-financing to support the levels of

Corporate Control and Idiosyncratic Vision, 125 YALE L.J. 560, 580-81 (2016) (using Apple and Ford as examples where asymmetric information and differences of opinion led investors to doubt entrepreneurial pursuit of a business idea); Leon Yehuda Anidjar, Toward Relative Corporate Governance Regimes: Rethinking Concentrated Ownership Structure Around the World, 30 STAN. L. \& POL'Y REV. 197, 205 (2019) (summarizing theoretical and temporal studies of more or less concentrated ownership structures); Daniel P. Cipollone, Risky Business: A Review of Dual Class Share Structures in Canada and a Proposal for Reform, 21 Dalhousie J. Legal Stud. 62, 71 (2012) (noting that dual-class structure provides a controlling minority shareholder with a protected position from corporate takeovers, allowing other shareholders to garner long-term benefits from the controller's vision); Bebchuk \& Kastiel (2017), supra note 7, at 611 (Snap used a dual-class structure, stating in its IPO documents that this would enable a long-term focus); see also Martijn Cremers et al., The Life-Cycle of Dual Class Firms: From IPO to Sunset, 32 (ECGI Working Paper No. 550, 2018) (finding it plausible that both public and controlling shareholders benefit from having the dual class structure available).

54. See supra note 15.

55. E.g., SHLEIFER, supra note 17 (asserting the short-termism of institutional investors); Gilson \& Kraakman, supra note 17 (same).

56. See supra note 17.

57. See supra FIGURE 1. In relation to the potential for dual-class structure to drive value for tech-companies generally, albeit from a U.K. perspective, see Reddy, supra note 8.

58. Reddy, supra note 8, at 329-30 (noting that dual-class-structure can enable investment in long product-cycles with long-term benefits, which may not be easily observable to the public markets in the short-term). 
growth required may not be available for preprofit companies, which is common for growth-phase tech-companies with long product-cycles. ${ }^{59}$

Related to long-termism, dual-class stock can also engender innovation and risk-taking. Although a controlling stockholder in a OSOV corporation will be similarly insulated from the public markets, the relevant controller may be reluctant to take the risks (which, if unsuccessful could cause a decline in share price) required to truly innovate when such a large portion of that controller's wealth is tied-up in the corporation, ${ }^{60}$ especially if the controller is aiming to crystallize any of its investment through a stock sale in the future. With dual-class stock, on the other hand, the controller, by reducing its exposure to share price fluctuations, can take risks that may prove, eventually, to be highly successful. ${ }^{61}$ A strategy can be pursued where several projects are undertaken over an extended period of time, where some will prove to be "winners" and others "losers". The strategy will be successful so long as the controller is confident that, over time, there will be more "winners" than "losers," or at least the "winners" will generate greater financial returns than the "losers." Being able to take such risks can promote innovation, ${ }^{62}$ which is critical to success in the era of Big Tech. ${ }^{63}$

59. See id. at 7 (innovative tech companies who lack a robust profits history and have long product-cycles may struggle to find debt-funding). With a lack of debt funding for preprofit corporations, equity funding becomes the only option for growth.

In 2016, seventy-five percent of U.S. tech-company IPOs involved preprofit companies. Hong Kong Exchanges \& Clearing Ltd., New Board Concept Paper, 15 (2017), [https://perma.cc/TW8Q-JVR3].

60. See Alex Edmans, Blockholders and Corporate Governance, 6 AnNu. REv. FIN. ECON. 23, 33 (2014) (noting that a stockholder's concern about idiosyncratic risk can induce the firm to forgo risky investments despite their long-term potential); Brian Cheffins, Corporate Law and Ownership Structure: A Darwinian Link? 25 U. S. WALES L.J. 346, 357 (2002) (same); Ronald J. Gilson \& Bernard S. Black, The LaW and Finance of CORPORATE ACQUisitions, at 784 (1995) (same).

61. See Scott W. Bauguess et al., Shareholder Diversification, Corporate Risk Taking, and the Benefits of Changing to Differential Voting Rights, 36 J. BANK FIN. 1244, 1245 (2012) (describing the payoffs of a differential voting rights structure, which can include risk-sharing, restructuring that enables corporate focus, and long-term increases in firm value); GILSON \& BLACK, supra note 60, at 784 (same); Fischel, supra note 53, at 140 (same); Henry T.C. Hu \& Bernard S. Black, The New Vote Buying: Empty Voting and Hidden (Morphable) Ownership, 79 S. CAL. L. REV. 811, 852 (2006) (same); Cipollone, supra note 53, at 69 (same).

62. Bansi Nagji \& Geoff Tuff, Managing Your Innovation Portfolio, HaRv. Bus. Rev. 69 (May 2012) (finding that certain tech companies taking on bigger risks became transformational in their innovations); Reddy, supra note 8, at 331-33 (observing that tech companies can benefit from risk taking facilitated by dual-class stock).

63. "Big Tech" is the contemporary trend in major tech-companies with inordinate market, public and societal influence. See Rana Foroohar, We Need to Talk about Big Tech, 
Another benefit of dual-class stock structure to outside stockholders can be garnered where the controller of the corporation is a visionary manager viewed by the market as essential to the continuing success of the business. ${ }^{64}$ If the controller only holds a sliver of the equity, it has more to lose than gain by selling its stock and exiting the business, since the controller will lose its pecuniary and non-pecuniary private benefits. ${ }^{65}$ The knowledge that the controller is committed to the business for the long-haul can also encourage other managers to make investments of firm-specific human capital into the business, without fear of capricious removal if shortterm profits are moribund. ${ }^{66}$ Similarly, the bonding mechanic can also foster the development of long-lasting relationships with other employees and third-party customers and suppliers, ${ }^{67}$ who can proceed with the confidence that the strategy of the firm will not be abruptly altered by an unexpected change in management team. Dual-class stock can therefore confer substantive benefits on a tech-company, the success of which is contingent upon the investment of substantial firm- and product-specific human capital by employees, and the development of long-term relationships with suppliers and customers in circumstances where the pool of copacetic third-party counterparties is small.

\section{Where does the Balance Lie?}

A balance clearly exists between the positive and negative aspects of dual-class stock. The eternal debate has centered around which of those aspects dominate in dual-class stock corporations. If sufficient legal, regulatory, market and psychological constraints exist to contain the ability of controllers of dual-class corporations to expropriate outside stockholders, one may expect that the positive qualities will dictate. ${ }^{68}$

Fin. Times (Oct. 3, 2017) (emphasizing Big Tech's monopoly power, its ability to influence elections, and the growing fear that Big Tech represents an existential threat).

64. Reddy, supra note 8, at 333-35; Fischel, supra note 53, at 137.

65. Albert H. Choi, Concentrated Ownership and Long-Term Shareholder Value, 8 HARV. BUS. L. R. 53, 68 (2018).

66. DeAngelo \& DeAngelo supra note 53, at 35-36; David J. Denis and Diane K. Denis, Majority Owner-Managers and Organizational Efficiency, 1 J. CORP. FIN. 91, 106 (1994); Reddy, supra note 8, at 330; EKKEHART BÖHMER ET AL., The Effect of Consolidated Control on Firm Performance: The Case of Dual-class IPOs, in EMPIRICAL IsSUES IN RAISING EQUiTy CAPITAL 95, 111 (Mario Levis ed., 1996).

67. Reddy, supra note 8, at 330-31 and 333.

68. See, e.g., infra note 212 (discussing the treatment of conflicted transactions in the U.S.). To a lesser extent, market-based constraints can also have a bearing, since, even if the controller has divested of substantial equity, if that controller still owns sufficient "skin-inthe-game", he/she may still be constrained from expropriating outside stockholders 
However, if controllers of dual-class firms have free reign to abuse their positions, with a lack of an equity constraint where substantial cash-flow rights have been divested by the controller, the incentive to extract private benefits to the detriment of the interests of the company may be too great an urge to resist. Clearly, in many cases, the positive qualities of dual-class firms overshadow detrimental private benefit extraction. Total returns on Google stock, fifteen years after its IPO, were around 400\%, compared to approximately $250 \%$ for the S\&P 500 during the same period. ${ }^{69}$ During that period, Google became the third largest company in the world by market capitalization. ${ }^{70}$ Similarly, total returns on Facebook stock soared by $400 \%$ in the seven years after its IPO in 2012, compared to approximately $170 \%$ for the S\&P 500 during the same period..$^{71}$ Three of the best-performing stocks of the last decade have been dual-class corporations. ${ }^{72}$ However, are these examples the exceptions that prove the rule, or are they indicative of a broader trend?

The preceding question can only be answered by evaluating the empirical evidence on dual-class firms as a whole. By comparing the performance of dual-class firms to matched OSOV firms, a picture can be painted as to how the controllers of dual-class firms behave in practice, and their rationale for adopting dual-class structure in the first place. From the perspective of outside stockholders, the empirical evidence can be instructive as to whether dual-class structure is, on average, an agent of "good" or "evil." In Parts II to IV, the existing empirical evidence will be

excessively for fear of a precipitous fall in stock price affecting wealth and the ability to generate future equity funding for growth at a reasonable price (e.g., Reddy, supra note 8, at 339). Psychological constraints can also restrain controllers (e.g., Peter Flocos, Toward a Liability Rule Approach to the "One Share, One Vote" Controversy: An Epitaph for the SEC's Rule 19c-4, 138 U. PA. L. Rev. 1761, 1777 (1989-1990)); See also Ronald Gilson, Controlling Family Shareholders in Developing Countries: Anchoring Relational Exchange, 60 STAN. L. REV. 633, 643 (2007); Dyck \& Zingales, supra note 51, at 539 (arguing aspects such as reputation and legacy, as well as social norms and public opinion can be strong constraints on controller actions).

69. Anna Hecht, If You Invested \$1,000 in Google 10 Years Ago, Here's How Much You'd Have Now, CNBC (Oct. 8, 2019).

70. Tim Bradshaw \& Adam Samson, Alphabet Overtakes Apple As World's ThirdBiggest Company, Fin. Times (Jan. 3, 2019).

71. Anna Hecht, If You Invested \$1,000 in Facebook at Its IPO, Here's How Much Money You'd Have Now, CNBC (Oct. 25, 2019).

72. Philip van Doorn, These Are the 20 Best-Performing Stocks of the Past Decade, and Some of Them Will Surprise You, MARKETWATCH (Dec. 28, 2019). The list of twenty bestperforming stocks of the last decade includes Regeneron Pharmaceuticals, Constellation Brands, and Charter Communications, all of which are dual-class stock corporations (Council Inst. Invs., Dual Class Companies List, (March, 2021) https://www.marketwat ch.com/story/these-are-the-20-best-performing-stocks-of-the-past-decade-and-some-of-them -will-surprise-you-2019-12-09 [https://perma.cc/CCW2-FEKA]. 
analyzed, segregated into different performance measures, ${ }^{73}$ before collating the evidence to complete the picture and ascertain the implications for future policy-making.

\section{THE EMPIRICAL EVIDENCE ON FIRM VALUE}

\section{A. The Measure of Firm Value}

Several U.S. studies have assessed the correlation between firm value and dual-class structure. The vast majority of those studies use a performance measure that compares the market capitalization of a corporation's stock with the value of its assets. The most common measurement is “Tobin's Q." Tobin's Q is the ratio of market value of stock to replacement cost of assets. ${ }^{74}$ Given the difficulties in ascertaining the replacement cost of assets, Tobin's Q is usually reduced to the ratio of market value of stock to book value of assets.

The underlying premise of using Tobin's $Q$ in firm valuation studies ${ }^{75}$ is that market value, as deduced in the numerator of the ratio, reflects future expectations and assessments of risks, ${ }^{76}$ since, if all information regarding present and future performance is efficiently assimilated by the market, ${ }^{77}$

73. Empirical studies on dual-class stock were collated using the search terms "dual-class stock" or "dual class stock" and "empirical" in the online academic repositories SSRN, JSTOR and Hein Online. Searches were also conducted for citations of the principal studies. For the purposes of this paper, "event-based" empirical studies, which assess the impact of announcements of mid-stream post-IPO recapitalizations of OSOV companies into dual-class stock firms, have been excluded. In the 1980s and early 1990s, after an influential study by Megan Partch (Megan Partch, The Creation of a Class of Limited Voting Common Stock and Shareholders' Wealth, 18 J. FIN. ECON. 313 (1987)), a series of event-based studies were conducted. However, event-based studies are especially susceptible to endogenous contamination, with the impact of share price being driven by extraneous events surrounding the recapitalization, rather than the shift to dual-class stock per se. Therefore, significant doubt can be levied against the validity of event-based study data in the dual-class stock sphere. Furthermore, mid-stream recapitalizations into dual-class stock have become progressively rarer since the NYSE officially permitted the use of dual-class stock at IPO (see supra notes 31-36, and accompanying text), limiting the extent of contemporary analysis of such recapitalization phenomena. Accordingly, such studies have been excluded from this paper.

74. See, e.g., James Tobin and William Brainard, Asset Markets and the Cost of Capital, 1, 1 (Cowles Foundation Discussion Paper No. 427, 1976). Technically, the numerator should also include the market value, and the denominator the book value, of the company's liabilities, but it is common practice to assume that the two cancel each other out.

75. Originally, Tobin's Q was developed as a macroeconomics determinant, but it was eventually hijacked by purveyors of firm profitability - as an early use of the concept in this sphere, see Eric Lindenberg and Scott Ross, Tobin's q Ratio and Industrial Organization, 54 J. Bus. 1 (1981).

76. Robert Bartlett \& Frank Partnoy, The Misuse of Tobin's Q 1, 13 (2018).

77. Supra note 15. 
share price should embrace investor predictions of future profitability. Accordingly, market capitalization can diverge from asset value, as represented by the Tobin's $\mathrm{Q}$ ratio. If Tobin's $\mathrm{Q}$ for a dual-class company is lower than one, it could suggest that the market is discounting the value of its future cash-flow or earnings growth, as a result of anticipated expropriation by the controller or the presence of an entrenched underperforming management team. ${ }^{78}$ If the market is truly efficient, and the relevant study examines Tobin's Q over a sufficiently long period of time, mispricing should be smoothed out over time, such that initial undervaluations, due to concerns that a controller will expropriate outside stockholders, will, if such expropriation does not in fact take place, erode as investors identify that the stock is undervalued. Equally, if expropriation of outside stockholders does take place, to the extent that it overshadows any positive attributes of dual-class firms, Tobin's Q will remain low over the relevant time period as the market predicts continued expropriation. However, as will be discussed later in this Part II, Tobin's Q may not be the pure determination of managerial future performance as sometimes presupposed, and, furthermore, doubt can be cast on the efficiency of the market. $^{79}$

Usually, in dual-class firm value studies, the market value of stock is the value of the inferior-voting stock (grossed-up at the same per-share value to reflect the proportion of equity represented by enhanced-voting stock), since it represents the value accruing to outside stockholders ${ }^{80}$ (and, in any event, usually only the inferior-voting stock is listed) ${ }^{81}$ Although "true" firm value would reflect the sum of the market value of the inferiorvoting and enhanced-voting stock, where the authors are seeking to determine the effect of dual-class structure on outside stockholders, the price of the inferior-voting stock is more critical, since it will track predictions of future performance. The price of enhanced-voting stock, on the other hand, will also encompass the value of the controller's private benefits of control. ${ }^{82}$

78. Randall Morck et al., supra note 14, at 294.

79. SHLEIFER, supra note 17; Gilson \& Kraakman supra note 17.

80. Adams \& Ferreira, supra note 12, at 63.

81. Gompers et al., supra note 52, at 1056.

82. ISS in collaboration with Sherman \& Sterling LLP and the European Corporate Governance Institute as commissioned by the European Commission, Report on the Proportionality Principle in the European Union at 12 (18 May, 2007). 


\section{B. Firm Value Empirical Studies - the Results}

Dual-class firm value studies compare firm value for dual-class firms to matched OSOV firms. The matching criteria varies between studies, but, conceptually, adequate matching can control for extraneous determinants of firm performance such as firm size, industry, firm age and sales growth.

Thirteen U.S.-specific studies have been reviewed for the purposes of this Part II. As shown in Figure 2, these studies show a mix between positive ${ }^{83}$ negative ${ }^{84}$ and no correlation between firm value and dual-class structure, ${ }^{85}$ with one further study finding correlations varying depending upon firm-qualities or extraneous circumstances. ${ }^{86}$ Certain of the studies, though, present a more nuanced picture, either educing differing correlations after sub-sampling, or, due to the types of firms examined, prompt more detailed interpretations. These studies are discussed in more detail below.

\section{Detailed analysis of Firm Valuation Studies}

Figure 2 clearly shows that the U.S. empirical evidence trends toward firm value negatively correlating with dual-class structure, with most U.S.

83. BÖHMER ET AL., supra note 66.

84. Gompers et al., supra note 52; Anderson, supra note 46; Smart et al., What's In a Vote? The Short- and Long-Run Impact of Dual-Class Equity on IPO Firm Values, $45 \mathrm{~J}$. ACCOUnT. ECON. 94 (2008); AmOAKO-AdU ET AL., supra note 46; Belén Villalonga \& Raphael Amit, How Do Family Ownership, Control and Management Affect Firm Value?, 80 J. Fin. ECON. 385 (2006); Bradford Jordan et al., Growth Opportunities, Short-Term Market Pressure, and Dual-Class Share Structure, 41 J. CORP. FIN. 304 (2016); Hoi \& Robin, supra note 48. It should be noted that Hoi and Robin showed that the intensity of the negative correlation increased with the proximity of the controller to management, to the extent that where the controller was not involved in management, a positive correlation was found between firm value and dual-class structure (however, the sample size for dual-class firms where the controller was an outsider was very small). Furthermore, Anderson et al. found a positive correlation between firm value and dual-class structure where the corporation was not family (including founder) controlled (however, again, the sample size for non-family controlled dual-class firms was very small - see supra note 46).

85. Wayne Mikkelson \& Megan Partch, The Consequences of Unbundling Managers' Voting Rights and Equity Claims, 1 J. CORP. Fin. 175 (1994); Hyunseob Kim \& Roni Michaely, Sticking Around Too Long? Dynamics of the Benefits of Dual-Class Structures, 1, 5 (ECGI Working Paper, N. 590/2019); Cremers et al., supra note 53; Thomas Chemmanur et al., Management Quality and Antitakeover Provisions, 54 J. LAW ECON. 651 (2011). It should be noted that Chemmanur et al. assessed antitakeover devices (including dual-class stock) generally, and only assessed Tobin's Q at the time of IPO.

86. Ronald Anderson et al., Founders, Heirs, and Corporate Opacity in the United States, J. FIN. ECON. 205 (2009). 
empirical studies finding dual-class firms to be valued less than matched OSOV firms. However, prior to drawing conclusions, certain caveats should be highlighted. The period of the relevant study may influence the results obtained. The oft-cited study by Gompers et al (2010) (GIM), which found a negative correlation between dual-class structure and firm value, examined a period between 1995 and 2002. ${ }^{87}$ Smart et al (2008), in examining a similar period of 1990 to 1998, also found a negative correlation. ${ }^{88}$ However, Kim and Michaely (2018) examined a much more extensive period, between 1971 and 2015, and, overall, found no significant correlation between the two qualities. ${ }^{89}$ Similarly, Cremers et al $(2018)^{90}$ examining a period from 1980 to 2015, also found no correlation overall. Kim and Michaely attributed the divergence from GIM's results on the longer sample period and were, in fact, able to replicate the GIM findings when restricting the sample period to between 1995 and 2002. From the existing evidence, it is not possible to categorically ascertain how the time period influences results, although it does seem that negative correlations may be driven by periods commencing in the mid-1990s and encompassing later years. As with GIM, negative correlations were also found for sample periods of 1994 to 2000 (Villalonga and Amit (2006)) ${ }^{91}$, 1999 to 2000 (Hoi and Robin (2010)) $)^{92}, 2001$ to 2007 (Amoako-Adu et al (2013) $)^{93}, 1994$ to 2011 (Jordan et al (2016)) $)^{94}$ and 2001 to 2015 (Anderson $(2017))^{95}$. In contrast, samples restricted to periods earlier than the mid1990s were associated with either positive correlations (Böhmer et al $(1996)^{96}$, examining 1984 to 1988) or no correlation (Mikkelson and Partch $(1994)^{97}$, examining 1976 to 1987). The lack of brightline rules is emphasized, though, by Chemmanur et al $(2011)^{98}$ which found no significant relationship between the two qualities for the period 1993 to 2000 .

87. Gompers et al., supra note 52.

88. Smart et al., supra note 84.

89. Kim \& Michaely, supra note 85.

90. Cremers et al., supra note 53.

91. Villalonga \& Amit, supra note 84 . Although, note that this study only examined the effect of dual-class structure on family or founder-owned firms specifically (see infra note 106 , and accompanying text).

92. Hoi \& Robin, supra note 48.

93. AMOAKO-ADU ET AL., supra note 46.

94. Jordan et al., supra note 84.

95. Anderson et al., supra note 46.

96. BÖHMER ET AL., supra note 66.

97. Mikkelson \& Partch, supra note 85.

98. Chemmanur et al., supra note 85. 


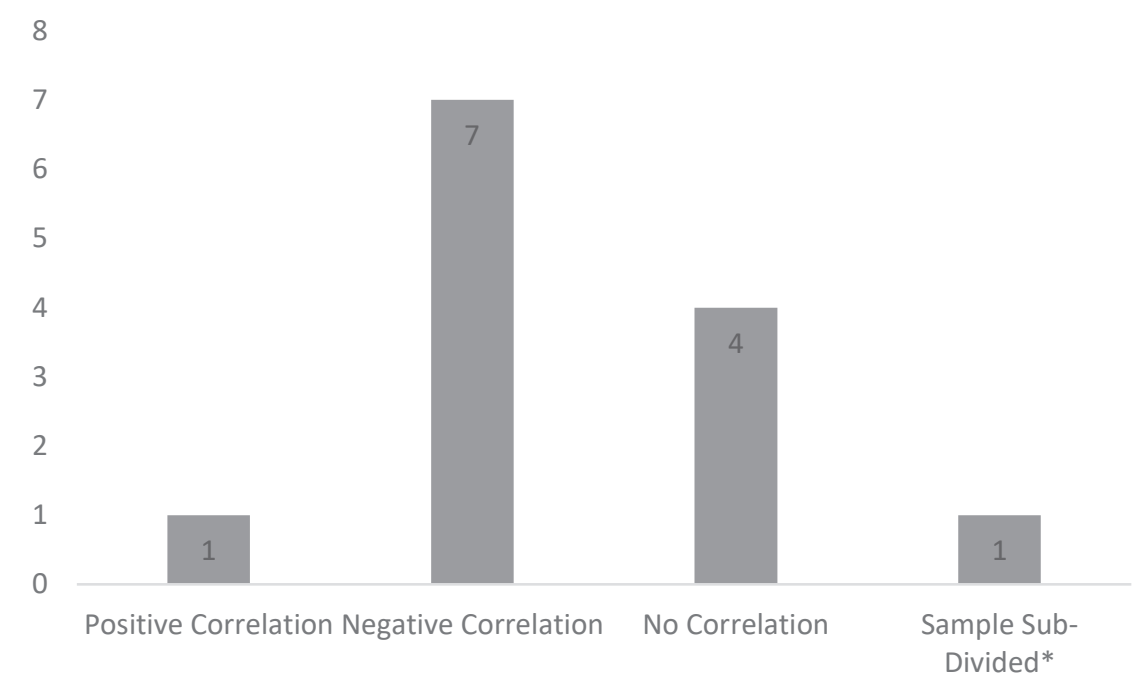

FIGURE 2 - U.S. DUAL-CLASS STOCK FIRM VALUE

STUDIES.* indicates that the study did not assess a correlation between firm value and dual structure for the entire sample of dual-class firms, but, instead, assessed correlations between different sub-categories of dual-class firms and firm value

Further research in this area would be welcome, since it would be germane to determine exactly how and why the influence of dual-class structure on firm value varies over different historical periods. For example, institutional investors have had, at least publicly, a historic aversion to dual-class structure, ${ }^{99}$ and their progressive domination of the landscape over time ${ }^{100}$ may have had an effect on how dual-class firms are valued. Furthermore, the types of firms that have adopted dual-class structure has also evolved, with a surge in tech-firms adopting dual-class structure after Google's 2004 IPO, ${ }^{101}$ and firm-type may impact upon the effect of dual-class structure. ${ }^{102}$ Economic conditions may also have a critical impact on the effect of dual-class structure. For instance, periods of

99. See supra note 6 (citing institutional investor distaste for dual-class shares).

100. See supra note 29 (detailing the rise of institutional investors). As of 2018, institutions owned $62.4 \%$ of U.S. equities. The Securities Industry and Financial Markets Association, CAPITAL MARKETS FACT BoOK, at 60, https://www.sifma.org/wp-content/upl oads/2019/09/2019-Capital-Markets-Fact-Book-SIFMA.pdf) [https://perma.cc/SM2Y-EMG D]. The 2018 figure may, though, be understated. See infra note 247.

101. See supra FIGURE 1 (detailing the rise of dual-class IPOs in the technology industry).

102. See infra Part VI (discussing the effect of firm attributes). 
financial strife, such as during financial crashes, ${ }^{103}$ may increase the incentives on controllers of dual-class firms to extract private benefits of control when equity returns on profits are significantly condensed. The explanation may, though, be more prosaic and, instead, simply relate to study design improving, ${ }^{104}$ or investors becoming more proficient in appraising the effect of dual-class structure, ${ }^{105}$ over time. The differences between studies may even not be related to time effects at all, and merely a factor of the use of different techniques in matching dual-class firms to similar OSOV firms. A better understanding of the time factor would aid in interpreting the empirical evidence by providing color on whether firm value results are driven by the merits and detriments of dual-class stock, or by investor perception of the structure.

Another caveat to the interpretation of the results is raised by those studies that subsample dual-class firms into different categories. Villalonga and Amit (2006) examined the effect of family- (including founder-) control on firm value. They found that founder-control (but not descendant-control) had a positive effect on firm value. ${ }^{106}$ The addition of mechanisms that enabled the controller to maintain control with a disproportionately lower level of cash-flow rights, such as dual-class stock, attenuated the positive effect of founder-control. ${ }^{107}$ This moderation of the positive effect of founder-ownership was not so great, though, to eliminate the positive bias of founder-control compared to non-founder-control firms generally. ${ }^{108}$ These results have particular relevance to the assessment of dual-class stock since dual-class firms are primarily family- (including founder-) controlled. ${ }^{109}$ Even though the adoption of dual-class structure may reduce firm value in such firms, the very existence of dual-class stock could be crucial in persuading founders to list their companies. Without dual-class stock, founders may be unwilling to list since, with OSOV structure, they would either lose control, or retain control but be unable to

103. Outside of the U.S., studies have indicated that the incentives on controllers to expropriate outside stockholders may have been amplified during the Asian financial crisis. See infra notes 151-152, and accompanying text.

104. See Allaire, supra note 13, at 8 (raising the prospect that differences in empirical results between older and more recent studies may be explained by improvements in study design).

105. See Gompers et al., supra note 52, at 1061 (asserting that, by 1995, investors would have had substantial information about dual-class companies and sufficient time to digest the relevant information); see also Kim \& Michaely, supra note 85, at 16 (noting the potential impact of temporal changes in the perceived value of dual-class stock).

106. See Villalonga \& Amit, supra note 84, at 406 ("[t]he results show that the positive value effect of family firms . . is entirely attributable to first-generation family firms").

107. Villalonga \& Amit, supra note 84, at 406.

108. Id.

109. See supra note 46. 
divest of the desired level of equity and unable to issue sufficient equity for further growth. ${ }^{110}$ Therefore, if dual-class structure enables more listings of founder controlled companies, which are seemingly valued more by the market, there should be less focus on the marginal negative effect of dualclass structure on firm value in those firms. However, since the results are driven by founder-controlled, rather than descendant-controlled, firms, from a policy perspective, thought should be directed as to whether restrictions should be placed upon the identity of individuals who can hold dual-class stock. ${ }^{111}$ If the benefits of founder-control are eliminated by the founder ceding control to descendants, the rationale to promote dual-class stock is similarly curtailed if the enhanced-voting stock is no longer held by the founder. ${ }^{112}$

Although, overall, Chemmanur et al $(2011)^{113}$ did not find any relationship between the adoption of antitakeover provisions (including dual-class stock) and firm value, they found correlations when subdividing firms into those with high and low-quality management. ${ }^{114}$ Firms with high quality management displayed greater firm valuations if they implemented antitakeover provisions, resonating with the normative bonding hypothesis benefit of dual-class stock as described above. ${ }^{115}$ Conversely, firms with lower quality managers, presumably adopting antitakeover provisions

110. This has been described as a "catch-22" scenario for founders, deterring them from taking their companies public (Reddy, supra note 8, at 324).

111. Structuring appropriate restrictions on the use of dual-class structure is outside the scope of this article. However, a number of studies have broached mandating sunset provisions that convert enhanced-voting shares into inferior-voting shares upon the original holder transferring those shares to other persons. See, e.g., Winden, supra note 8, at 927 ("[h]igh vote shares should covert on virtually any transfer . . "); see also Reddy, supra note 8 at 342 (mentioning the conversion of shares upon transfer); see also Moore, supra note 8, at 145 (advocating the benefits of mechanisms that convert enhanced-voting shares into inferior-voting shares upon transfer). Interestingly, a number of dual-class corporations have voluntarily adopted so called transfer-driven sunset clauses, although they are often subject to specific exemptions. E.g., Facebook, Amended and Restated Certificate of Incorporation of Facebook, Inc. (June 20, 2016) at Article IV, Section 3; Google, Amended and Restated Certificate of Incorporation of Alphabet Inc. (Oct. 2, 2015) at Article IV, Section 2; Snap, Amended and Restated Certificate of Incorporation of Snap Inc. (filed Feb. 2, 2017) at Article $\mathrm{V}$, section 6.

112. See Winden, supra note 8 at 927 (arguing for the elimination of those dual-class shares on the basis that they no longer support the founder's "vision"); see also Reddy, supra note 8 at 342 (discussing whether enhanced-voting stock should be converted into inferiorvoting stock upon transfer, even where the transferee is a family member).

113. Chemmanur et al., supra note 85 .

114. The authors used characteristics related to experience, education, CEO dominance, median tenure and tenure heterogeneity as determinants of management quality. Chemmanur et al., supra note 85 , at 661-662.

115. See supra notes $64-67$, and accompanying text. 
principally to protect themselves from their own poor performance, showed worse firm values with adoption of such provisions. Additionally, Anderson et al (2009), ${ }^{116}$ using bid-ask spread as a proxy for asymmetric information among investors, and analyst errors as a proxy for information availability, found that transparent dual-class companies positively correlated with firm value, whereas those with opaque disclosure protocols negatively correlated with firm value. Reverse causation may be a significant issue, though, since poor disclosure may be a result of managers attempting to obscure private benefit extraction that is detrimental to the company.

The stage of a company's life-cycle may also have a bearing on how dual-class structure affects firm value. The discussion in Part I(B) highlighted the utility of dual-class stock for high-growth techcorporations, and several studies are suggestive that firm value will be benefited by dual-class structure while firms are growing. The studies by Jordan et al (2016), ${ }^{117}$ which showed negative correlations between firm value and dual-class structure, and Cremers et al (2018) ${ }^{118}$ and Kim and Michaely (2018), ${ }^{119}$ which both found no relationship between firm value and dual-class structure after matching criteria were applied, also subsampled firms using different measures of life-cycle. Jordan et al (2016) found that for high-growth firms, dual-class structure is correlated with positive firm value (with the opposite the case for low-growth firms). Cremers et al (2018) found that an initial positive correlation between firm value and dual-class structure at IPO dwindled with time passing after IPO, with dual-class firms showing lower Tobin's Q than matched OSOV firms six years after IPO. Kim and Michaely found that mature dual-class firms (12 years or older) had worse firm valuations than matched mature OSOVfirms, but younger (less than 12 years-old) dual-class firms had better firm valuations than matched young OSOV firms. The significance of these studies is discussed below.

\section{Interpreting Firm Valuation Studies}

Although, generally, firm valuation studies indicate that dual-class structure is detrimental to firm value, sufficient evidence exists to suggest that for certain types of firms or in certain conditions, dual-class structure may in fact be positively correlated with firm value. In certain circumstances, perhaps relating to widespread poor economic conditions,

116. Anderson et al., supra note 86 .

117. Jordan et al., supra note 84.

118. Cremers et al., supra note 53.

119. Kim \& Michaely, supra note 85. 
private benefit extraction may be incentivized. ${ }^{120}$ Additionally, older firms may drive the overall negative correlations. ${ }^{121}$ When a firm is within a growth-phase, dual-class structure can be beneficial to all stockholders by enabling a controller to cause the company to invest in R\&D and other long-term investment in order to secure long-term growth and development of products, without concerns that the management team will be punished by outside stockholders as a result of short-term deficits in profitability. As discussed above, this quality is especially pertinent where the long-term impact of investment is not easily observable by the market. ${ }^{122}$ As a firm matures, and investment opportunities decline, profits are not invested, increasing the opportunities for a controller to expropriate outside stockholders. ${ }^{123}$ Unsurprisingly, management quality can also influence results, with dual-class structure assisting good quality management in improving firm value. ${ }^{124}$ On the other hand, with poor quality managers the positives otherwise attributable to dual-class firms by insulating management become negatives; private benefit extraction by such managers will, therefore, not be compensated by the propensity to produce better long-term profits.

Assuming that firm valuation studies accurately portray whether or not dual-class structure is beneficial or detrimental to outside stockholders, it would seem that dual-class structure generally creates detriments for outside stockholders, but for certain types of firms (and possibly in certain conditions) dual-class structure can be beneficial to all stockholders. If that interpretation were credible, further empirical research should primarily focus on discerning the types of firms for which dual-class structure creates

120. See infra notes 151-52, and accompanying text.

121. See text accompanying supra notes 117-19.

122. See supra Part I(B).

123. АмOAKO-ADU ET AL., supra note 46, at 196 suggested that the low Tobin's Q for dual-class firms was driven by firms with high free cash-flows. A Canadian firm value study also found that for firms which adopted mechanisms creating a divergence between voting and cash-flow rights, those with high free-cash flow showed significantly lower Tobin's Q than matched firms with no such divergence. Yves Bozec \& Claude Laurin, Large Shareholder Entrenchment and Performance: Empirical Evidence from Canada, 35 J. BuS. FIN. \& ACCT. 25, 33 (2008). This reasoning also chimes with a Swiss study which found that, after sub-sampling, dual-class firms with cash-flow insufficient for investment opportunities (which therefore required external financing), correlated with higher firm valuations compared to matched OSOV firms, and a negative relationship was educed for those dualclass firms that did not require external financing - the authors opined that controllers were constrained from expropriating outside stockholders when equity funding was required for growth, for fear of increasing the cost of capital. Stephan Nüesch, Dual-Class Shares, External Financing Needs, and Firm Performance, 20 J. MgmT. \& Governance 525, 542 (2016).

124. See supra notes 113-15, and accompanying text. 
positive firm value, and, potentially, policy should be developed to restrict the use of dual-class stock to specific types of firms and/or to formulate outside stockholder protections that are triggered upon the occurrence of conditions in which expropriation of outside stockholders is likely to dominate. However, as discussed in the next section, it is equivocal that firm value, in the context of dual-class firms, is indicative of prior, existing or future management performance or expropriation of outside stockholders.

\section{E. Words of Warning}

A fair degree of skepticism can be directed from various angles at the supposition that firm value equates to management performance and, in the context of dual-class stock, uncompensated expropriation of outside stockholders. Firstly, the very use of Tobin's Q brings with it inherent issues. While some authors have described Tobin's Q as the "capitalized value of agency costs", ${ }^{125}$ others have accepted that the measure is very noisy. ${ }^{126}$ A finding that OSOV firms have higher Tobin's Q than dual-class firms essentially means that an intangible asset is being valued higher in OSOV firms, or an unspecified liability is being factored into the price of dual-class firms. That intangible asset or unspecified liability does not necessarily represent the manner in which assets are being managed, but, instead, could reflect the nature of the assets of the business. ${ }^{127}$ Relevant intangible assets could, for example, include not only future growth and good management, but also elements such as goodwill, position in the market, and patents held. ${ }^{128}$ Furthermore, as above, ${ }^{129}$ although the denominator in Tobin's Q is "replacement cost of assets" it is usually estimated using the book value of the corporation's assets, and, accordingly, most studies are not determining true Tobin's Q. ${ }^{130}$ Results can, therefore, be biased by companies using different depreciation

125. Bozec \& Laurin, supra note 123 , at 33.

126. See Morck et al., supra note 14, at 296 ("Although Q is undoubtedly a very noisy signal of management performance ...").

127. See Mikkelson \& Partch, supra note 85 , at 188 ("[a] shortcoming of this measure is that the value added can reflect the nature of the firm's assets ...").

128. See Morck et al., supra note 14, at 296 ("Tobin's Q is high when the firm has valuable intangible assets in addition to physical capital, such as monopoly power . . goodwill, a stock of patents ..." ).

129. See supra Part II(A).

130. See Bartlett \& Partnoy, supra note 76, at 26 ("[s]imple $q$ generates such extreme outliers because of the questionable assumptions with regard to both the numerator and the denominator utilized in estimating Simple q"). 
schedules and inventory accounting rules. ${ }^{131}$ Also, certain intangible assets are "unbooked intangible assets" and not included in book value; for example, complex products such as financial derivatives are not booked, ${ }^{132}$ and, importantly, expenditure on R\&D, knowledge and intellectual property are often not capitalized. ${ }^{133}$ Extraneous divergences also exist between firms in relation to the booking of intangible assets - for instance, differences can exist in the manner in which goodwill is booked between businesses that build, versus those that buy, intangible assets. ${ }^{134}$ A high estimated Tobin's Q could be based upon the market's valuation of unbooked intangible assets rather than its assessment of the management team's qualities and level of entrenchment. ${ }^{135}$

Second, ascertaining causation in firm value, and, indeed, in any, empirical studies is challenging. Empirical studies notoriously suffer from endogeneity issues - there may be a greater preponderance of certain types of firms adopting dual-class structure, ${ }^{136}$ and the qualities of those firms may be driving firm valuation results rather than their capital structure. ${ }^{137}$ Although most of the studies reviewed, in order to moderate this issue, use matching criteria to evaluate dual-class firms against matched OSOV firms, there are numerous endogenous variables that could influence the adoption of dual-class stock, including not only commonly utilized matching criteria, such as industry-type and firm size, but also growth-profile, type of ownership, age and economic conditions. As noted by Adams and Ferreira (2008), many studies do not control for endogeneity properly, ${ }^{138}$ and, correspondingly, categorical proof of causation between capital structure and firm value is elusive. Additionally, some commentators have put forth the concept of "efficiency of choice of structure," pursuant to which the capital structure which is overall best for a relevant firm and its various

131. Bartlett \& Partnoy, supra note 76 , at 27.

132. Id.

133. Id. at 29

134. Id.

135. Id. at 14 .

136. See Adams \& Ferreira, supra note 12, at 62 (noting firm characteristics that "are correlated with the extent to which voting control is concentrated"); Hu and Black, supra note 61 , at 852 (acknowledging that divergences between economic ownership and voting control may be endogenously determined); Chen Li et al., Ownership Structure and the Cost of Corporate Borrowing, 100 J. FIN. ECON. 1, 10 (2011) (noting concerns of endogeneity due to certain ownership structures with firm-specific characteristics unaccounted for in the study's model).

137. See Jill Fisch \& Steven Solomon, The Problems of Sunsets, 99 B.U. L. REV. 1057, 1073 (2019) (analyzing selection effects as "the primary issue with finance studies of dual class stock" and noting the ways in which companies that select dual class structures differ from those that select single class structures).

138. Adams \& Ferreira, supra note 12, at 85. 
stakeholders will be chosen in each case. ${ }^{139}$ Although it may not be credible that the choice of capital structure is efficient in every case, if, at least for some companies, the relevant capital structure has been implemented due to it being most conducive to the performance of the relevant company, the empirical evidence on firm value may be skewed toward there being no overall positive or negative correlation with capital structure. ${ }^{140}$

Finally, and crucially, the propensity for firm value to reflect management performance and/or expropriation should be cast against the extent to which firm value may merely reflect the market's preconceived opinion of dual-class stock. ${ }^{141}$ If the market is not efficient, ${ }^{142}$ investors may, when they invest in dual-class firms, assume that the theoretical detriments of dual-class firms will overshadow the theoretical benefits,

139. See Kenneth Lehn et al., Consolidating Corporate Control: Dual-class Recapitalizations Versus Leveraged Buyouts, 27 J. Fin. ECON. 557, 566 (1990) (arguing that "ownership structures are endogenously determined and guided by value maximization"); Harold Demsetz \& Kenneth Lehn, The Structure of Corporate Ownership: Causes and Consequences, 93 J. POL. ECON. 1155, 1156 (1985) (finding selection of a firm's ownership structure is determined by value maximization and advantages and disadvantages to the firm's shareholders).

140. See Zohar Goshen \& Richard Squire, Principal Costs: A Theory for Corporate Law and Governance, 117 Colum. L. REV. 767, 814 (2017) (noting the conflicting findings of current empirical literature). For example, for a firm where short-term signaling is more important, an OSOV-structure may be optimal, whereas a dual-class structure could be optimal for firms where long-term strategy is more conducive. See Mike Burkart et al., Large Shareholders, Monitoring, and the Value of the Firm, 112 Q.J. ECON. 693, 718 (1997) (noting an increase in ownership concentration as long-term returns become more important).

141. A U.K.-study showed how market perception can affect firm valuation over and beyond actual management performance or expropriation of outside stockholders - the level of the discount attached to dual-class firms was correlated with the level of negative media coverage of dual-class firms, even where such negative coverage was not associated with increased expropriation behavior in dual-class firms. Fabio Braggion \& Mariassunta Giannetti, Changing Corporate Governance Norms: Evidence from the Dismissal of Dual Class Shares in the U.K., J. Fin. InTERMEDIATION 15, 23 (2019). In fact, those periods were accompanied by greater average monthly stock returns for portfolios of dual-class firms compared to OSOV firms. Id. at 27. Certain "event-based studies" have shown that upon midstream recapitalizations of OSOV into dual-class stock, the market reacts negatively. See Gregg Jarrell \& Annette Poulsen, Dual-Class Recapitalizations as Antitakeover Mechanisms: The Recent Evidence, 20 J. FIN. ECON. 129, 130-31 (1988); Lehn et al., supra note 139, at 576-77; Gordon, supra note 28, at 28-29. Accordingly, firm valuation studies showing dualclass firms discounted as compared to matched OSOV firms, may simply be indicative of the market's ideological reaction to dual-class stock persisting long after IPO (or recapitalization to the extent that dual-class stock was adopted post-IPO) notwithstanding the actual performance of those companies.

142. See e.g., SHLEIFER, supra note 17 (noting that the rational behavior of arbitrageurs can lead to the mispricing of long-term assets); Gilson \& Kraakman, supra note 17 (revisiting market efficiency through behavioral finance). 
whether or not detrimental private benefit extraction does in fact exceed the benefits that can accrue to dual-class firms. An alternative rational explanation is that investors view dual-class firms as risky investments due to the ease with which controllers can expropriate outside investors, and the incentives on controllers to expropriate outside investors. ${ }^{143} \mathrm{By}$ discounting those companies, the market has organically protected itself from the risks - even if the risks do manifest themselves as real-world expropriation of outside stockholders, the losses to those stockholders will be minimized by the fact that they have invested in the stock at a lower price than would have been the case if the same firm had adopted OSOV. It is therefore apposite to consider whether actual expropriation of outside stockholders is taking place in dual-class firms, to the extent that it outweighs the benefits of dual-class structure, or whether the foregoing hypotheses of market perception or hedging against risk explains the discounts that apply to dual-class firms generally. By examining whether dual-class firms perform worse generally than OSOV firms from the perspective of non-firm value performance measures, the puzzle presented by firm value studies may be solved. Apropos, the next two Parts of this article will review the empirical evidence pertaining to the correlation between dual-class structure and buy-and-hold stock returns, and operating performance, respectively.

\section{BUY-AND-HOLD STOCK RETURN STUDIES}

\section{A. Relevance of Buy-and-Hold Stock Return Studies}

In the dual-class stock context, buy-and-hold stock return studies assess the long-term ${ }^{144}$ returns that would be received from a notional portfolio of dual-class firm inferior-voting stock compared to a notional portfolio of matched OSOV firms over the same period of time. In essence, such studies can demonstrate whether investors in inferior-voting stock of dualclass firms are better or worse served than those that invest in the stock of OSOV firms.

Buy-and-hold stock return studies buttress firm valuation studies by ascertaining whether differences in share prices between dual-class firms and OSOV-firms correlate with the returns actually earned by stockholders.

143. See Anderson, supra note 46, at 19 (noting the substantially greater risk outside investors bear for holding dual class shares).

144. The buy-and-hold stock return studies reviewed generally track those returns over periods of three to eight years after IPO or recapitalization into dual-class structure. Anderson examined an extended period of 2001-2015. Anderson, supra note 46. 
In an efficient market, all information with regards to the future performance of a company is accurately assimilated by the market, ${ }^{145}$ and, therefore, if the detriments of dual-class structure outweigh the benefits of the structure, the stock of dual-class firms will be discounted compared to the stock of OSOV firms. The market is anticipating that a dual-class firm will not increase to the same value as an OSOV-firm over the same period of time; investors will acquire the inferior-voting stock of the dual-class firm at a lower price, and thereby receive a similar return to what they would have received had they invested in an OSOV-firm instead. As has been discussed in Part II, the trend in firm valuation studies is that dualclass structure is correlated with negative firm value. If the discounts applied do indeed accurately embody lower future managerial performance compared to OSOV firms, or disproportionate expropriation of outside stockholders, the returns received by portfolios of dual-class firms should be similar to the returns received by portfolios of matched OSOV-firms. If those returns, instead, diverge significantly, the contention that firm valuation discounts applied to dual-class firms truly reflects managerial performance and behavior can be questioned.

\section{B. Buy-and-Hold Stock Return Studies - the Results}

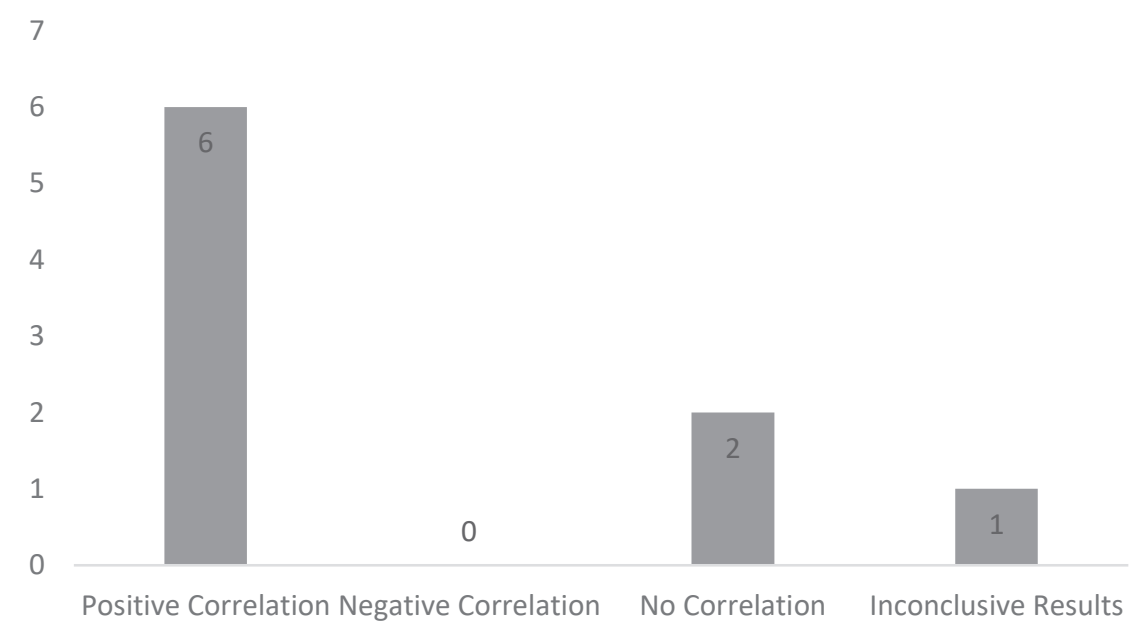

FIGURE 3 - U.S. DUAL-CLASS STOCK BUY-AND-HOLD STOCK RETURN STUDIES

In the U.S., a handful of buy-and-hold stock return studies have been conducted in the dual-class stock sphere. Nine such studies were reviewed.

145. See Fama, supra note 15, at 383 (defining an efficient market). 
As shown in Figure 3, the studies either showed that dual-class stock portfolios were associated with higher abnormal returns ${ }^{146}$ or no abnormal returns, ${ }^{147}$ with one further study finding inconclusive results. ${ }^{148}$

\section{Detailed Analysis of Buy-and-Hold Stock Return Studies}

As set-out in Figure 3, most of the studies reviewed showed portfolios of dual-class firms to generate greater stock returns than portfolios of OSOV firms. It should be noted that one of the studies showing a positive buy-and-hold stock return correlation with dual-class firms only educed economic and not statistically significant results, and only where controllers had sold-down equity at the time of recapitalization from OSOV to dual-class structure. ${ }^{149}$ Additionally, another study showing a positive correlation acknowledged that the results were heavily influenced by those firms that issued further equity after recapitalization from OSOV to dualclass structure. ${ }^{150}$ As discussed further in the next section, these two studies perhaps allude to the fact that positive returns on dual-class stock are driven by particular types of companies or controllers.

Beyond the caveats offered by the two studies above, unfortunately, greater sub-sampling of dual-class firms has not been conducted from a buy-and-hold stock return perspective. The information available as to the

146. See BöHMER ET AL., supra note 66, at 109 (concluding going public with a dual class equity structure has net benefits such as higher equity returns); Anderson et al., supra note 46, at 23 (arguing for a positive relation between returns and size of the wedge); Dimitrov \& Jain, supra note 37, at 347 (documenting dual-class firms in the sample earn large positive abnormal returns); Bauguess et al., supra note 61, at 1251 (finding a "pattern of superior profitability ... associated with dual class firms ... "); Ahn et al., Synthetic Governance (Eur. Corp. Governance Inst., Working Paper No. 693, 2020) (showing a putative dual-class index earning a positive return); Chemmanur et al., supra note 85, at 681 (assessing antitakeover devices, including dual-class stock, generally). Figure 3 does not include a further non-academic study that found U.S. dual-class firms to outperform the MSCI index between November 2007 and August 2017. Dimitris Melas, Putting the Spotlight on Spotify: Why Have Stocks with Unequal Voting Rights Outperformed?, MCSI (Apr. 3, 2018) https://www.msci.com/www/blog-posts/putting-the-spotlight-on/0898078592 [https://perma. cc/RXJ8-S5SH].

147. See Cremers et al., supra note 53, at 24 (concluding stocks of dual-class firms have "normal returns"); Smart et al., supra note 84, at 106 (finding "dual-class firms show little or no sign of significant positive or negative abnormal stock returns after the IPO").

148. Mikkelson \& Partch, supra note 85, at 191. The study found negative stock returns for dual-class firms (relative to matched firms) in the first calendar year after recapitalization into dual-class structure, and positive returns in calendar years two through four. The level of statistical significance for each of the four calendar years post-recapitalization was not sufficient for the authors to form a conclusion.

149. Bauguess et al., supra note 61, at 1251.

150. Dimitrov \& Jain supra note 37 , at 360. 
levels of returns yielded from different types of dual-class firms is sparse, and certainly not quite as fulsome as the relevant information available from firm valuation studies. Further research would be welcome that attempts to connect firm valuation studies that separate dual-class firms by type to the notional returns that they may generate. As with firm valuation studies, time periods may be relevant, and further U.S. research in that regard would also be welcome. For example, two Asian studies showed that stock returns associated with companies that had implemented mechanisms creating a divergence between cash-flow and voting rights were lower than other companies during the Asian financial crisis ${ }^{151}$ and the Korean financial crisis, ${ }^{152}$ respectively, during the late 1990s. Outside of the financial crises, neither study deduced such stark differences between dual-class firms and OSOV firms. It is therefore possible that during periods of economic turmoil, dual-class firm returns may decline greater than OSOV firm returns, due to the greater incentives to expropriate outside stockholders ${ }^{153}$ as discussed in the section on firm valuation studies above, but further study is required before forming conclusive policy implications.

\section{Interpreting Buy-and-Hold Stock Return Studies}

In the U.S., the trend in buy-and-hold stock return studies is that portfolios of dual-class stock produce better returns than portfolios of OSOV stock. The assertion should be qualified by the small number of studies in this area, but none of the U.S. studies have shown dual-class portfolios to generate worse returns than OSOV portfolios. Two studies suggested that positive returns are driven by firms where the controller has sold-down substantial equity, or where the company has issued further equity. ${ }^{154}$ In relation to the controller selling-down of equity, those antagonistic to dual-class firms would consider the reduced levels of "skinin-the-game" to indefensibly increase the incentives on the controller to

151. See Michael Lemmon \& Karl Lins, Ownership Structure, Corporate Governance, and Firm Value: Evidence from the East Asian Financial Crisis, 58 J. Fin. 1445, 1455 (2003) (finding firms in which insiders have high control rights but few cash flow rights "will exhibit the largest declines in firm value during the crisis").

152. Jae-Seung Baek et al., Corporate Governance and Firm Value: Evidence from the Korean Financial Crisis, 71 J. FIN. ECON. 265, 289 (2004) (finding a negative relationship between holding period returns and the divergence between controller economic and voting ownership during the Korean financial crisis).

153. See Lemmon \& Lins, supra note 151, at 1466 (indicating incentives to expropriate outside shareholders may have been amplified during the Asian financial crisis); Baek et al., supra note 152, at 310 (same).

154. Bauguess et al., supra note 61, at 1251; Dimitrov \& Jain., supra note 37, at 360. 
extract private benefits to the detriment of the company, but the higher levels of returns suggest that over-compensatory benefits to outside stockholders are generated in such circumstances by enabling the controller, through diversifying wealth, to cause the company to take greater risks and pursue a successful long-term vision. ${ }^{155}$ In relation to greater dual-class stock returns being generated upon the issuance of further equity, the results conform to the hypothesis that dual-class structure is particularly beneficial to high-growth firms, since equity issuances could be indicative of a desire to fund further growth.

Resonating with the high-growth hypothesis, a further study indicated that the higher returns associated with dual-class firms could be driven by firms which have undergone IPO most recently. ${ }^{156}$

At the very least, the results show that investors are adequately protecting themselves from the risks inherent in dual-class structure, and may, in fact, be earning a premium from investing in dual-class firms. With firm valuation studies primarily showing that the market prices-in a discount on dual-class firms, and buy-and-hold stock return studies showing that investors earn stronger returns when investing in those dualclass firms, it would suggest that investors are discounting dual-class firms due to their fear of the risks of excessive expropriation by controllers, but those risks are not manifesting themselves in real-world excessive expropriation over time. ${ }^{157}$ Although institutional investors do not

155. See discussion supra Part I(B).

156. Ahn et al., supra note 146, at 136.

157. A number of non-U.S. studies are also pertinent. See Martin Holmén, Foreign Investors and Dual Class Shares (2011) (unpublished manuscript) (on file with author). The author notes, in the context of an influx of foreign investors into the Swedish markets, that such investors applied a discount to dual-class firms independent of actual expropriation. See Fabio Braggion \& Mariassunta Giannetti, At the Origins of the Non-Voting Shares' Discount: Investor Preferences vs. Fundamentals, SEMAnTic Scholar, 1, 23 (2012). Analyzing the U.K. market, the authors studied pricing differences between voting and non-voting stock and found that the discount applied to non-voting stock was unjustified by ex post returns, opining that the discount was applied simply as a result of investor preference for OSOV. See Beni Lauterbach \& Anete Pajuste, The Long-Term Valuation Effects of Voluntary Dual Class Share Unifications, 31 J. CORP. FIN. 171, 173 (2015) (noting that the market over-estimated the agency cost benefits upon the unification of dual-class structures into OSOV in Israel). 
apparently shun dual-class firms, ${ }^{158}$ they possibly expect a premium or "reward" over time just for taking the risk of investing in such firms. ${ }^{159}$

In Part II of this article, it was shown that for certain types of dual-class firms, firm valuations are higher than matched OSOV firms. A reasonable interpretation is that the market is sufficiently sophisticated to determine which dual-class firms should be discounted (due to the detriments likely overshadowing the benefits of the structure) and which should be valued higher (due to the benefits likely outweighing the potential detriments). However, without similar sub-sampling of firms in buy-and-hold stock return studies, it is difficult to ascertain whether the market is so sufficiently sophisticated, since it is quite possible that portfolios of dualclass firms that display firm valuation premia compared to OSOV firms still generate greater stock returns than matched OSOV firms. In such a case, the interpretation would be that the market is still attaching a discount to such firms, albeit that the market's perception of the benefits accruing to such types of firms by implementation of dual-class stock outweigh the detriments. Limited empirical evidence suggests that this may, indeed, be the case. ${ }^{160}$

An important outcome from the results and interpretation above is that, as will be discussed in further detail in Part V of this article, the proposition

158. Evidence is mixed as to whether institutional investors are more or less likely to invest in U.S. dual-class stock. There is no evidence, though, that such investors significantly shun U.S. dual-class firms. Certain studies have shown that institutional investor ownership in U.S. dual-class firms is the same or greater than such ownership in OSOV firms. See Anderson et al., supra note 46, at 28 ("[o]verall, our analysis does not support the notion that institutions avoid or shun dual class family firms, rather, we document that these sophisticated investors appear to hold nearly the entire free float in super-voting family firms."); Smart et al., supra note 84, at 99 (finding dual-class IPO firms have higher institutional ownership than do OSOV IPO firms); Scott Smart \& Chad Zutter, Control as a Motivation for Underpricing: A Comparison of Dual and Single-Class IPOs, 69 J. Fin. ECON. 85, 98 (2003) (noting institutional investors hold a larger fraction of publicly traded equity of dual-class firms than single-class firms). Although other studies have, in contrast, shown less institutional ownership of dual-class firms as compared to OSOV firms, the differences are not striking and certainly not indicative of institutional investors completely shunning dual-class firms. See Kai Li et al., Do Voting Rights Affect Institutional Investment Decisions? Evidence from Dual-Class Firms, 37 Fin. Mgmt. 713, 720 (2008) (finding "institutions of every type hold less of the shares in dual-class firms than they do in similar single-class firms"); Jinhee Kim et al., Multi-Class Shares Around the World: The Role of Institutional Investors (November 2018) (unpublished manuscript (on file with author)) (arguing institutional investors harbor a strong aversion against multi-class firms).

159. See Anderson et al., supra note 46, at 19 (arguing investors may expect to earn a risk premium for investing in dual-class firms).

160. See infra note 228 and accompanying text ("limited empirical evidence does indeed indicate that even those firms that are valued higher by the market are still being discounted when compared to their operating performance, but with the discount not sufficient to mask the positive effect of high operating performance on firm value"). 
sometimes levied at dual-class firms that they are, based upon their lower firm values, harmful to outside investors, can be challenged when considering the buy-and-hold stock return empirical evidence. There is no evidence that outside stockholders are harmed by dual-class firms from a wealth-maximization perspective.

\section{E. Words of Warning}

Two crucial concerns should be noted with respect to buy-and-hold stock return studies. Firstly, not many U.S. studies have been conducted in this area, and many of those that have been completed do not cover the most recent period of the tech-industry's embrace of dual-class structure. A broader set of studies covering more recent time periods would be instructive.

Second, buy-and-hold stock return studies can also be tainted by endogeneity concerns in the same way as firm valuation studies. As with firm valuation studies, endogeneity issues can be somewhat alleviated by controlling for various variables with the use of appropriate matching between OSOV firms and dual-class firms. However, it is challenging to perfectly match against all potential variables without acutely reducing sample-size, ${ }^{161}$ and the results of buy-and-hold stock return studies may be biased in the same way as firm value studies. In particular, it has been remarked that more robust regression specifications are required than those that are usually employed when identifying causal effects on stockholder returns. ${ }^{162}$ Correspondingly, the inference that dual-class stock is especially beneficial for high-growth firms can, in and of itself, raise concerns. It is quite possible that, particularly in a post-Google world where dual-class structure is being prolifically adopted by high-growth tech-firms, that a sample of dual-class firms, especially in more recent studies, encompasses a disproportionate number of high-growth firms as compared to OSOV samples. Better stock return results may, thus, be driven by high-growth firms, rather than dual-class structure per se. Controlling for such effects is difficult, since determining indications of high-growth can be challenging, and it further brings into focus the importance of further research on the impact of time periods, since the types of firms choosing dual-class structure will have evolved over time.

161. Indeed, it was noted in Cremers et al. that sample-size was significantly diminished by their use of extensive matching. Supra note 53, at 17.

162. Bartlett \& Partnoy, supra note 76 , at 46. 


\section{OPERATING PERFORMANCE STUDIES}

\section{A. Operating Performance Measures}

Operating performance studies can elaborate upon the empirical evidence gleaned from firm valuation and buy-and-hold stock return studies, by determining whether dual-class firms are more profitable than OSOV firms. If dual-class structure insulates poorly performing management teams or serves as a front for excessive private benefit extraction by controllers, one would expect that such firms will display poorer operating performance than matched OSOV firms.

Operating performance studies use a variety of accounting measures of performance to assess dual-class firms. The most common measure is "return on assets" (ROA) which equates to earnings (sales less costs and expenses) before interest, tax, depreciation, and amortization (EBITDA), divided by assets. By linking profits to the assets of the company, the measure can indicate how well management is managing the assets of the company, and, therefore, ties profitability to the size of the firm. Crucially, the measure will also be impinged if the controller is utilizing those assets to benefit it personally to the detriment of the company. Derivatives of ROA, such as operating income before depreciation plus interest income (OIBD) over assets, are also sometimes used. "Return on equity" (ROE), being net earnings over equity, is another measure often used, and ties profitability to the market capitalization of the company, and so, again, controls for the size of the firm. "Return on invested capital" (ROIC) is a further measure sometimes used and corresponds to operating income (adjusted for tax) divided by total debt and shareholder equity less cash. The intention of ROIC is to gauge how efficiently a company uses its capital by linking earnings to investment projects. ${ }^{163}$ Additionally, numerous other ancillary measures of firm profitability are used in operating performance studies, as described in the detailed analysis below, such as sales growth, operating margin, and EBITDA divided by sales.

\section{B. Operating Performance Studies - the Results}

Eleven operating performance studies were reviewed which, as presented in Figure 4, either showed that dual-class firms outperform matched OSOV firms by at least one performance measure, (although two of those studies only showed positive results where, respectively, the

163. See David Benoit, The Hottest Metric in Finance: ROIC, Wall Street Journal (May 3, 2016, 3:45 PM) (discussing how companies have been using ROIC to gauge its management of the capital and the business in general). 
controller had divested of equity or the company had subsequently issued further stock), ${ }^{164}$ or showed no difference in operating performance between dual-class and OSOV firms. ${ }^{165}$ One of the studies that showed no correlation did, after sub-sampling, find that certain types of dual-class firms do outperform OSOV firms (with other types of dual-class firms underperforming OSOV firms). ${ }^{166}$ Figure 4 sets-out the findings.

\section{Detailed Analysis of Operating Performance Studies}

As presented in Figure 4, several studies show that dual-class firms display better operating performance than matched OSOV firms. Cremers et al. (2018), using six-yearly snapshots between 1985 and 2015, found dual-class firms to have greater ROA and ROE than matched OSOVfirms, ${ }^{167}$ although sales growth was not statistically different between the capital structures. ${ }^{168}$ Similarly, a study by Böhmer et al. (1996) found, between 1984 and 1988, greater EBITDA and ROA for dual-class firms compared to OSOV firms in the year after IPO and through three years after IPO, while sales and assets were not statistically different. ${ }^{169}$ Dualclass firms were able to produce better operating results with similar sales and assets growth. After three years post-IPO, dual-class firms still outperformed OSOV firms, with their rates of decline of ROA, ROE, and the ratio of net operating income to sales significantly less than OSOVfirms. ${ }^{170}$ For IPOs between 1980 and 2008, Arugaslan et al. (2010) found that dual-class firms had higher profit margins ${ }^{171}$ than industry-matched OSOV-firms in the year after IPO. ${ }^{172}$ Examining IPOs between 1993 and 2000, Chemmanur et al. (2011) found that although through four years post-IPO, all U.S.-firms displayed declining OIBD ${ }^{173}$ over assets, OIBD

164. Onur Arugaslan et al., On the Decision to Go Public with Dual Class Stock, 16 J. CORP. FinANCE 170 (2010); Cremers et al., supra note 53; BÖHMER ET AL., supra note 66; Lehn et al., supra note 139; Bauguess et al., supra note 61; Dimitrov and Jain, supra note 37; Chemmanur et al., supra note 85 . Chemmanur et al. assessed antitakeover devices (including dual-class stock) generally.

165. Gabriel Morey, Council of Inst. InV'rs, Multi-Class Stock and Firm Value: Does Multi-Class Stock Enhance Firm Performance? A Regression Analysis, (2017); Mikkelson \& Partch, supra note 85; Smart et al., supra note 84; Kim \& Michaely, supra note 85.

166. Kim \& Michaely, supra note 85 .

167. Cremers et al., supra note 53, at 18.

168. Id. at 19

169. BÖHMER ET AL., supra note 66, at 112, 114.

170. Id. at114.

171. Ratio of the difference between sales and earnings after interest and tax to sales.

172. Arugaslan et al., supra note 164 , at 177.

173. Operating income before depreciation plus interest income. 


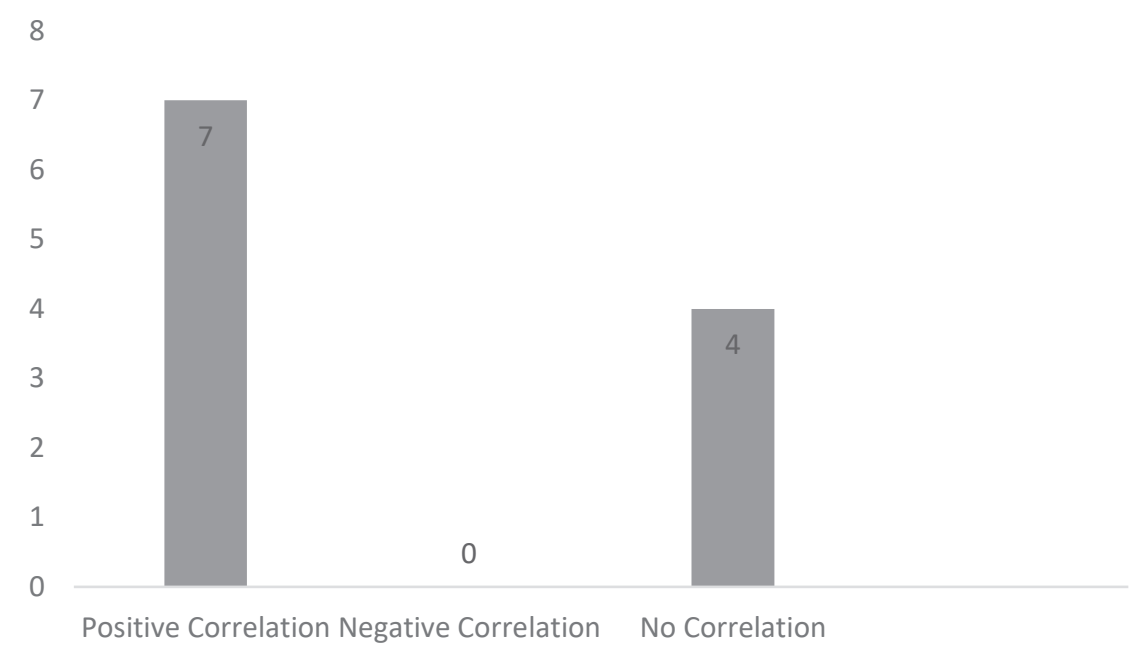

\section{FIGURE 4 - U.S. DUAL-CLASS STOCK OPERATING PERFORMANCE STUDIES}

over sales, ROA, and profit margin, those that had implemented antitakeover provisions (which included dual-class stock) saw lower rates of decline. ${ }^{174}$ Similar to their results in relation to firm value above, the authors also found that those firms with high quality management outperformed all other types of companies across nearly all tested years post-IPO if they had also implemented strong antitakeover provisions. ${ }^{175}$ Lehn et al. (1990), examining mid-stream recapitalizations of OSOV structures into dual-class structures between 1976 and 1987, found that operating income divided by sales significantly increased in the periods of one year before, to one year, two years and three years after recapitalization. ${ }^{176}$ The authors noted, though, that the positive results were concentrated within those firms that issued further equity. ${ }^{177}$ Similarly, Dimitrov and Jain (2006) also examined recapitalizing firms and found similar ROA and ROE between recapitalizing dual-class firms and matched OSOV firms, and greater growth rate for dual-class firms postrecapitalization into dual-class structure compared to matched OSOV firms, where those dual-class firms subsequently issued equity after the recapitalization; the authors therefore noted that dual-class firms could

174. Chemmanur et al., supra note 85, at 675.

175. Id. at 676 .

176. Lehn et al., supra note 139 , at 577.

177. Id. at 578 . 
outgrow matched OSOV firms, while maintaining steady profitability. ${ }^{178}$ It was opined that with higher growth and similar profitability, total profits must be growing at the same rate as the growth rate, meaning that dualclass structure likely allows those firms to take advantage of investment opportunities in a value-enhancing manner that creates higher abnormal returns over time for investors. ${ }^{179}$ Bauguess et al. (2012) found statistically significant increases in industry-adjusted ROA where the recapitalizations also entailed the incumbent controller selling-down equity. ${ }^{180}$

Kim and Michaely, with a long sampling period of 1971 to 2015, did not find any correlation between dual-class structure and operating performance when scrutinizing the samples of dual-class firms as a whole, but, after sub-sampling, they found that young (less than 12 years-old) dual-class corporations had statistically better operating margins ${ }^{181}$ than young OSOV corporations, and mature (more than or equal to 12 yearsold) dual-class corporations had statistically worse operating margins than mature OSOV corporations. ${ }^{182}$

Three studies found no correlation at all between operating performance and dual-class structure. Neither Smart et al. (2008), investigating ROA and EBITDA over book equity, in the 5-years postIPO ${ }^{183}$ nor Mikkelson and Partch (1994), evaluating a ROA proxy in the 4years post-recapitalization from OSOV into dual-class stock, ${ }^{184}$ found any correlations. Another study by Morey (2017) found that dual-class structure had no correlation with ROIC. ${ }^{185}$

\section{Interpreting Operating Performance Studies}

Notable by their absence are studies that found that dual-class firms perform worse than matched OSOV firms in accounting measures. The studies reviewed either show that dual-class firms perform significantly

178. See Dimitrov \& Jain, supra note 37, at 358, 359 and 363 (showing that dual-class firms on average grow substantially faster than their OSOV competitors, and that there's a clear link between dual-class recapitalization and growth).

179. Id. at 363. As discussed in Part III, the same authors found dual-class firms to generate greater stock returns than OSOV firms. See supra note 146 and accompanying text.

180. Bauguess et al., supra note 61, at 1251.

181. Operating income before depreciation over sales.

182. Kim \& Michaely., supra note 85 , at 17.

183. Smart et al., supra note 84, at 107.

184. Mikkelson \& Partch, supra note 85 , at 190 . The authors were attempting to replicate the earlier study by Lehn et al. (1990) which found a positive correlation between operating performance and dual-class structure. See supra notes 176-77, and accompanying text. The authors attributed their differing results to variations in matching criteria.

185. MOREY, supra note 165 , at 23. 
better than OSOV firms, or that there is no difference between the two types of capital structure. In relation to the latter category, one of those studies proceeds to show dual-class structure is, in fact, positively correlated with operating performance for certain types of dual-class firms. ${ }^{186}$ It therefore does not appear that, compared to OSOV firms, the management of dual-class firms overall either manage those firms less assiduously ${ }^{187}$ or make investment decisions that are worse for outside stockholders, ${ }^{188}$ both of which would be reflected by poorer operating performance. Just taking operating performance studies in isolation, controllers of dual-class corporations, notwithstanding the fact that they may retain total voting control, do not use their privileged (and entrenched) positions to make business or investment decisions that prioritize their interests over outside stockholders to the extent that it negatively affects the profits of the corporation on a net basis. The results do not exclude the possibility that detrimental expropriation is still taking place, but any expropriation taking place that could affect the generation of operating profits is overshadowed by the positive effects on profitability engendered by dual-class structure.

It is possible that those studies that discern positive correlations between dual-class structure and operating performance are being driven by specific types of dual-class firms, and that dual-class structure is beneficial for some firms and detrimental for others (with those firms for which it is positive dominating, or their operating performance results significantly compensating for the operating performance of those firms for which the structure is detrimental). Some of the empirical evidence suggests that this is the case. For example, Lehn et al. (1990) found that positive correlations were driven by firms issuing further equity. ${ }^{189}$ Dimitrov and Jain (2006) also found that firms issuing further equity post-recapitalization into dualclass structure performed better than matched OSOV firms. ${ }^{190}$ These studies corroborate the discussions above with respect to firm valuation and buy-and-hold stock return studies intimating that dual-class structure is beneficial for high-growth firms. The study by Kim and Michaely (2018)

186. $C f$. Kim and Michaely, supra note 85 , at 4, 5 (finding that operating performance is greater for young dual-class firms than young OSOV firms, but that mature dual-class firms perform worse than mature OSOV firms).

187. See Arugaslan et al., supra note 164, at 177 (showing that managers in dual-class firms are not using their control rights to be less diligent in managing the firms).

188. See BÖHMER ET AL., supra note 66, at 115 (finding that the authors' empirical evidence does not suggest that dual-class firms make poorer investments than OSOV firms, and that their results are not consistent with dual-class management expropriating holders of inferior-voting shares).

189. Lehn et al., supra note 139, at 578.

190. Dimitrov \& Jain, supra note 37, at 358-59 and 363. 
which found that operating performance was only positively correlated with dual-class structure in young firms also aligns with this theory, ${ }^{191}$ with the authors opining that dual-class structure can improve operating margins in young firms, but that such margins decline at a greater rate than OSOV firms. The finding by Bauguess et al. (2012) that positive correlations were only apparent for dual-class firms where the controller had divested of substantial equity is also pertinent. ${ }^{192}$ As with the interpretation of the authors' buy-and-hold stock return results above, it is possible (as also noted by the authors) that increased operating performance was a product of controller-diversification, through dual-class structure, leading to the business being managed in a manner beneficial to both outsiders and insiders. As discussed in Part I, such diversification supports risk-taking which may drive the increased operating performance. ${ }^{193}$ The findings of Chemannur et al. (2011) ${ }^{194}$ also highlight the identity of the controller as a possible determinant factor - dual-class structure may only be beneficial where the management team is talented. When the management team is not talented, managerial entrenchment may shift from being a benefit to being a detriment for outside stockholders.

Overall, even if it is the case that dual-class structure only improves operating performance for certain types of firms, when grouping all dualclass firm types together, there is no evidence that, overall, dual-class structure is detrimental to operating performance, notwithstanding the fact that the market appears to discount the value of dual-class stock. The juxtaposition between the market's attitude to dual-class stock and the actual performance of those firms that adopt dual-class stock will be discussed further in Part V.

\section{E. Words of Warning}

As ever, endogeneity rears its ugly head when discussing operational performance studies. Operating performance may be governed by the types of firms electing for dual-class structure rather than the by the adoption of the structure itself. A company that implements dual-class structure may be a firm that is already high-performing. On the other hand, in contrast to the postulation above that better buy-and-hold stock returns could be driven by a disproportionate number of high-growth firms adopting dual-class

191. Kim \& Michaely, supra note 85 , at 17 .

192. Bauguess et al., supra note 61, at 1251 .

193. See supra Part I(B) and, in particular, text accompanying notes 60-63.

194. See Chemmanur et al., supra note 85, at 676 (showing that IPO firms with high quality managers obtain better post-IPO financial performance through the adoption of antitakeover provisions). 
structure, often high-growth tech-corporations will be preprofit businesses, ${ }^{195}$ and therefore could drive mean operating performance downwards rather than upwards. Again, ascertaining the effects of endogeneity is challenging without further research. Studies indicating operating outperformance by dual-class firms which issue further equity post-adoption of dual-class structure ${ }^{196}$ may have been peculiarly affected by endogeneity issues; better operating performance may have been caused by the issuance of further equity rather than the adoption of dual-class structure. ${ }^{197}$ Another endogenous aspect to consider is whether better operating performance is being driven by the fact that dual-class firms are mainly family- (including founder-) owned. ${ }^{198}$ There is some evidence that family-controlled firms show better financial firm performance than nonfamily-controlled firms, ${ }^{199}$ invest more in R\&D where the controller is the founder, ${ }^{200}$ and show better operating performance than non-familycontrolled firms (with the positive effect attenuated by dual-class structure) ${ }^{201}$ Surprisingly, very few dual-class stock studies control for family-ownership, and further research in this area would be a valuable contribution to the discussion. However, following the discussion on firm valuation studies above, ${ }^{202}$ if dual-class structure can encourage founders to list their firms, the fact that dual-class samples include a disproportionate

195. See supra, note 59 and accompanying text.

196. Lehn et al., supra note 139; Dimitrov \& Jain, supra note 37.

197. The presupposition being that a company issuing further equity may require that equity to fund new, profitable projects.

198. See Anderson et al., supra note 46 (in examining Russell 3000 dual-class firms listed as of 2001, the authors found that only eleven percent were not family/founder-controlled); see also AMOAKO-ADU ET AL., supra note 46 (the authors' dual-class firm sample (20012007) consisted of $83.21 \%$ family-controlled firms).

199. See Marc van Essen et al., How does Family Control Influence Firm Strategy and Performance? A Meta-Analysis of US Publicly Listed Firms, 23 CoRP. Gov. 3, 11 (2015) (demonstrating through statistical modeling that family control is positively associated with financial performance).

200. See, e.g., Rüdiger Fahlenbrach, Founder-CEOs, Investment Decisions, and Stock Market Performance, 44 J. Fin. Quantitative Analysis 439, 446 (2009) (discussing that founder-CEO firms have higher capital expenditure to assets and higher ratio of R\&D expense to assets than non-founder-CEO firms); Essen et al., supra note 199, at 13 (demonstrating that founder-led family firms invest more in R\&D than non-family firms).

201. See, e.g., in relation to Canada, Michael King \& Eric Santor, Family Values: Ownership Structure, Performance and Capital Structure of Canadian Firms, 32 J. BANKING FIN. 2423, 2424 (2008) (showing that family owned firms have superior ROA, after having examined 613 Canadian firms from 1998-2005); in relation to Europe, Roberto Barontini \& Lorenzo Caprio, The Effect of Family Control on Firm Value and Performance: Evidence from Continental Europe, 12 EUR. FIN. MGMT. 689, 703 (2006) ("family corporations tend to exhibit clearly better valuation and operating performances than non-family firms").

202. See supra note 110 , and accompanying text. 
number of overperforming founder-owned firms is not necessarily fatal to inferences that dual-class structure is effectual in creating value for outside stockholders.

Interpreting the results pertaining to certain performance measures is also not trivial. For example, Morey (2017) equated high ROIC with longterm firm performance, ${ }^{203}$ when interpreting his findings that dual-class structure did not correlate with ROIC. Accordingly, the results were interpreted to show that dual-class structure is not a prerequisite to the deliverance of long-term performance. ${ }^{204}$ However, ROIC can also equate to short-term conduct - a company that substantially invests in long-term R\&D may suffer low ROIC as compared to companies that invest in projects that will bear immediate returns. ${ }^{205}$ Therefore, it is difficult to construe the results in terms of short- and long-termism, and an alternative interpretation is that, on average, the controllers of dual-class firms do not abuse their positions to cause such firms to invest in projects that are detrimental to outside stockholders to any greater extent than is seen in OSOV firms.

Another salient aspect is that several operating performance studies only assess operating performance over fairly short periods of three to five years. The studies may mask longer term trends, which, following the findings of Kim and Michaely (2018), ${ }^{206}$ may be crucial if the positive effects of dual-class structure on operating performance tails-off over time.

A final word of warning with respect to the hypothesis that dual-class firms perform at least as well, if not better, than OSOV firms, and therefore should not be considered harmful to outside stockholders, is that expropriation of profits could be occurring after-profits. ${ }^{207}$ The benefits of dual-class structure could be driving better operating performance, but, having generated those better profits, the controller of the firm is simultaneously or subsequently extracting pernicious private benefits. This would explain why firm valuation studies trend toward negative correlations with dual-class structure even though operating performance studies trend toward positive correlations - profits that would otherwise have accrued to the outside stockholders are expropriated by the controller resulting in lower firm values. However, it is difficult to envisage how private benefit extraction can, practically, take place without operating

203. MOREY, supra note 165 , at 2 .

204. Id. at 31 .

205. See Benoit, supra note 163 (explaining that a focus on ROIC may drive decisions that may be labeled as short term).

206. Kim \& Michaely, supra note 85 , at 3.

207. Morten Bennedsen \& Kasper Meisner Nielsen, The Principle of Proportional Ownership, Investor Protection and Firm Value in Western Europe 1, 26 (Eur. Corp. Governance Inst., Working Paper No. 134/2006). 
performance being impacted. For example, private benefit extraction through the controller abusing its entrenched management position to invest in pet or inefficient projects, extract high levels of remuneration, shirk or dedicate time to other unrelated enterprises, make decisions that benefit the reputation or self-image of the controller more than the interests of the company, or make poor acquisitions, would likely affect profitability, if not in the financial year of the relevant extraction, then in subsequent years. ${ }^{208}$ The fact that operating performance seems to remain robust for a period of time after implementation of dual-class structure concords with either such extraction not taking place, or taking place at such low levels that it is overshadowed by the operating performance benefits conveyed by the structure. The types of private benefits that could be extracted after-operations, are more likely to be concerns in low investor protection jurisdictions. If legal enforcement, conflicted transaction safeguards, financial press scrutiny, and accounting standards are lax, profits could be extracted by the controller or its related parties;

particularly, if such extraction involves outright stealing, operating performance may continue to appear robust even though expropriation of the public stockholders is occurring. However, in developed jurisdictions, such as the U.S., ${ }^{209}$ it is unlikely that such widespread stealing could occur, ${ }^{210}$ evidenced by the rarity of instances of prohibited or fraudulent extraction by controllers of dual-class firms in the U.S. ${ }^{211}$ With respect to

208. Henrik Cronqvist \& Mattias Nilsson, Agency Costs of Controlling Minority Shareholders, 38 J. Fin. \& QuANTitative ANALYsis 695, 714 (2003).

209. For an influential series of studies asserting the strength of investor protections in the U.S., see Rafael La Porta et al., Legal Determinants of External Finance, 52 J. FIN. 1131 (1997); Rafael La Porta et al., Law and Finance, 106 J. PoL. ECON. 1113 (1998); Rafael La Porta et al., Investor Protection and Corporate Valuation, 57 J. FIN. 1147 (2002). Although doubt has subsequently been levelled at the strength of investor protections in the U.S., Holger Spamann, The Antidirector Rights Index Revisited, 23 REV. FIn. STUD. 467 (2010); Simeon Djankov et al., The Law and Economics of Self-Dealing, 88 J. FIN. ECON. 430 (2008), further studies have explained those doubts by suggesting that the strength of U.S. protections lies in the accessibility of private enforcement rather than the strength of the legal protections themselves. Dionysia Katelouzou \& Mathias Siems, Disappearing Paradigms in Shareholder Protection: Leximetric Evidence for 30 Countries, 1990-2013, 15 J. CORP. L. STUD. 127 (2015). Either way, the U.S. presents a jurisdiction in which there exist substantive deterrents against controllers excessively expropriating outside stockholders.

210. Cronqvist \& Nilsson, supra note 208, at 714.

211. The only two obvious examples of extreme extraction through fraudulent behavior in U.S. dual-class firms were at the companies Adelphia Communications Corporation (Adelphia) and Hollinger International (Hollinger). In 2001, at Adelphia (a dual-class firm where the family of the founder held at the time around sixty-three percent of the voting rights, but only twenty-six percent of the cash-flow rights), the founder and his son, who were officers and enhanced-voting stockholders of the company, were convicted of obscuring 
conflicted transactions, in the U.S., the courts uphold strong conflict of interest standards, ${ }^{212}$ and, in any case, it is difficult to contemplate how such extraction could occur without harming profits in future years, which would, in contradiction to the empirical evidence, be reflected by a negative overall correlation between operating performance and dual-class structure. It is therefore usually in low investor protection jurisdictions that it is speculated that excessive private benefit extraction could be occurring after-profits, ${ }^{213}$ and, in the U.S., this is unlikely to be an explanation for dual-class firms showing lower firm valuations than OSOV firms even

liabilities, inflating earnings to meet market expectations, engaging in concealed self-dealing, and using corporate funds for personal purposes. The actions led to the bankruptcy of the company in 2002. Stuart Gilson \& Belén Villalonga, Adelphia Communications Corp. 's Bankruptcy, Harvard Business School Case No. 208-071, at 17 (2007) (revised in 2010). At Hollinger, Conrad Black was convicted of expropriating more than $\$ 400$ million from the company. Cipollone, supra note 53 at 74 . Black was CEO and chair of the corporation, and held, directly or indirectly, seventy-three percent of the voting rights in the company, but only thirty percent of the cash-flow rights. Blair Nicholas \& Brandon Marsh, Dual-Class: The Consequences of Depriving Institutional Investors of Corporate Voting Rights, HARV. L. SCH. F. ON CORP. GOVERNANCE (May 17, 2017), https://corpgov.law.harvard.edu/2017/05/17/dualclass-the-consequences-of-depriving-institutional-investors-of-corporate-voting-rights/ [https://perma.cc/8MAH-2Z68].

212. For example, in Delaware, if conflicted transactions are challenged by stockholders with no interest in the transaction, alleging that directors or officers have breached their fiduciary duties, the courts can subject the transaction to an "entire fairness review." Weinberger v. UOP, Inc., 457 A.2d 701, 703 (Del. 1983); Lucian A. Bebchuk \& Assaf Hamdani, Independent Directors and Controlling Shareholders, 165 U. PA. L. REV. 1271, 1282 (2017); Under an entire fairness review, unless specific processes have been followed by the company, the "business judgment rule," pursuant to which the courts will otherwise defer to the judgment of management, will not be applied. Kahn v. Tremont Corp., 694 A.2d 422,428 . If the transaction has been approved by a committee of independent directors, the burden of proof in relation to the entire fairness standard shifts to the plaintiff. Kahn v. Tremont Corp., 694 A.2d 422, 428 (Del. 1997). Although in the presence of a controlling shareholder, Delaware case law has been mixed in relation to whether the transaction can be "cleansed" in this way; the Courts appear to take into account any ties that the independent directors may have to the controller that could impact genuine independence. Bebchuk \& Hamdani, supra, note 212 , at 1289 . The burden can also be shifted if the company preapproves the transaction through a majority of the minority vote. Kahn v. Lynch Communication Systems, Inc., 638 A.2d 1110, 1115-16 (Del. 1994). In the context of controlling shareholder mergers, the Courts have recognised a dual-approval process such that if a committee of independent directors approves the transaction and it is further approved by a majority of the minority shareholders, an entire fairness review standard will no longer apply and the courts will revert to the business judgment rule. Kahn v. M\&F Worldwide Corp., 88 A.3d 635, 644 (Del. 2014); Jonathan Rosenberg \& Alexandra Lewis-Reisen, ControllingShareholder Related-Party Transactions Under Delaware Law, HARV. L. SCH. F. ON CORP. GOVERNANCE (Aug. 30, 2017), https://corpgov.law.harvard.edu/2017/08/30/controllingshareholder-related-party-transactions-under-delaware-law/ [https://perma.cc/852U-6TSM].

213. Bennedsen \& Nielsen, supra note 207, at 26. 
though they outperform those same OSOV firms on accounting measures of performance.

\section{MAKING SENSE OF THE EMPIRICAL EVIDENCE}

Although it is acknowledged that vagaries apply to the empirical evidence (as described in the "Words of Warning" for each set of empirical studies above), general trends are prevalent in the empirical evidence which can be pulled together. Somewhat of a conundrum is presented when bringing together the interpretations of the empirical evidence, discussed above, across different performance measures. Firm value studies generally show that dual-class structure is associated with a lower firm value than OSOV structure (although the relevant discounts do seem to be ameliorated for certain types of firms). However, such negativity is not emulated by buy-and-hold stock return and operating performance studies, and, in fact, many of the studies discussed in this article show dual-class firms to generate better returns for investors coinciding with better operating performance compared to OSOV-firms. Smart et al $(2008)^{214}$ is a useful firm valuation study, since it also researched operating performance, and therefore amalgamated both firm performance measures over the same samples of companies. It was representative of the overall trend, showing that although dual-class firms display lower firm values compared to OSOV firms, this is not due to lower operating performance after the structure is implemented. ${ }^{215}$

As discussed above in relation to operating performance studies, ${ }^{216}$ it is not credible that in a strong investor protection jurisdiction such as the U.S., that the nonconformity between the results garnered from firm value and operating performance studies can be explained by controllers extracting private benefits after-profits. A more likely explanation is that outside investors perceive dual-class stock to represent an incentivization structure where the extraction of private benefits by a controller that are detrimental to the company outweighs the benefits that the structure presents in enabling the controller to manage the business in a manner that is beneficial to all stockholders. As such, investors apply a discount to dual-class firms to protect themselves from potential expropriation that

214. Smart et al., supra note 84.

215. A number of non-U.S. studies also evidence the same juxtaposition between firm value and operating performance for dual-class firms. See Bennedsen \& Nielsen, supra note 207, at 25 (in relation to Europe); Anete Pajuste, Determinants and Consequences of the Unification of Dual-Class Shares, 15, 33 (Eur. Cent. BANK Working Paper No. 465, Mar. 2005) (same); King \& Santor, supra note 201, at 2424 (in relation to Canada).

216. See supra notes 209-13, and accompanying text. 
may cause a future decrease in profitability in circumstances where they are powerless to remove inside management. ${ }^{217}$ By applying the relevant discount to stock price, once the relevant expropriation takes place, the investors are not prejudiced and should earn similar returns to firms with OSOV structure. However, a number of the studies discussed above have found that those investors earn greater returns by investing in portfolios of dual-class firms than portfolios of similar OSOV firms. The study by Anderson et al $(2017)^{218}$ is pertinent, since it examined both buy-and-hold stock returns and firm valuation for the same sample of dual-class firms; dual-class firms had lower firm values than matched OSOV firms, but produced higher average buy-and-hold annual returns over a period between 2001 and 2015. It would seem that investors protect themselves "too much" - they are earning a premium by investing in dual-class firms. It is not justified that investors deserve a "reward" for investing in dualclass firms on the basis that expropriation which exceeds the benefits of the structure will occur at some point in the future, since operating performance studies, which mainly show better operating performance accruing to dual-class firms, indicate that the relevant excessive expropriation does not in fact come to pass. ${ }^{219}$

An alternative explanation for low firm valuations in the face of high operating performance is that investors may apply a discount to dual-class firms due to the ability of the controller to effectively veto takeovers that could otherwise earn investors a windfall to market price; however, again, such a discount is not empirically justified, since the empirical evidence is inconclusive as to whether takeovers of dual-class firms are in fact less prevalent than OSOV firms, ${ }^{220}$ and, to the extent that takeovers do occur, the windfalls to investors are generally greater. ${ }^{221}$ As such, it is unlikely

217. Smart et al., supra note 84, at 113.

218. Anderson et al., supra note 46.

219. See, e.g., Bauguess et al., supra note 61, at 1251 ("the incentives and interests of insiders and outside shareholders are more closely aligned after firms adopt a differential voting structure and insiders sell a considerable portion of their economic ownership").

220. See Bauguess et al., supra note 61, at 1249 (finding dual-class takeovers to be common); Onur Arugaslan et al., Monitoring as a Motivation for IPO Underpricing, $59 \mathrm{~J}$. FIN. 2403, 2409 (2004) (finding that dual-class firms are not less likely to be subject to takeovers than OSOV firms); Scott Bauguess et al., The Consequences of Recontracting Shareholder Control Rights at Closely Held Firms 3 (Feb. 22, 2006) (unpublished manuscript) (finding that firms that recapitalized into dual-class stock were taken over more often), cited in Adams \& Ferreira, supra note 12, at 64. But see Smart \& Zutter, supra note 158, at 102 (finding that the probability of an acquisition was less for dual-class firms); Cremers et al., supra note 53, at 21 (same); Mikkelson \& Partch, supra note 85, at 195-97 (same); Jordan et al., supra note 84 , at 310 (same).

221. Bauguess et al., supra note 61, at 1249; Smart \& Zutter, supra note 158, at 103). 
that such concerns can fully explain the discrepancy in firm values of dualclass firms when compared to their operating performances.

A variation on the "market for lemons" theme is in play. ${ }^{222}$ With incentives to extract excessive private benefits subsisting in dual-class firms, investors presume that the detriments of dual-class structure will prevail over the benefits of dual-class structure across the board, and therefore apply a discount to dual-class structure. ${ }^{223}$ In a pure "market for lemons" the "good" sellers of equity will be deterred from entering the market (from a fear of being valued on the same basis as "bad" sellers), leaving a market dominated by "bad" actors. ${ }^{224}$ Clearly, though, given the empirical evidence on buy-and-hold returns and operating performance, unlike a pure "market for lemons," "good" dual-class firm controllers are not deterred from listing. Pulling the pieces together to solve the puzzle, investor distaste of dual-class structure has led to them being disproportionately discounted by the market in a manner unwarranted by the actual operating performance of those firms. The unwarranted discounts accordingly lead to better returns achieved by investors in dualclass firms.

\section{FIRM AND CONTROLLER ATTRIBUTES AND THE IMPACT ON PERFORMANCE MEASURE STUDIES}

\section{A. Firm Attributes}

The discussion in Part V assessed the varieties of empirical evidence based upon the overall trends. However, to a degree, the existing empirical evidence indicates that performance measure correlations may vary with different dual-class firm characteristics. The attributes of the relevant firm may determine whether the potential benefits or the potential detriments of dual-class structure dominate. In Part I(B), the benefits that dual-class structure can bestow on tech-companies were extolled. For example, the "bond" that dual-class structure can create between controllers and the firm can be beneficial for tech-companies where customers or suppliers associate the controller's involvement with success and product-quality, which require employees to invest in significant firm-specific skills, and where the development of ingrained stakeholder relationships of trust and commitment is crucial. Similarly, dual-class structure can be beneficial to

222. See George A. Akerlof, The Market for "Lemons": Quality Uncertainty and the Market Mechanism, 84 Q.J. ECON. 488 (1970) (explaining the "Lemons Principle").

223. But see infra Part VI (discussing whether all dual-class firms are equal in the eyes of the market).

224. CHEFFINS, supra note 15 , at 130. 
high-growth tech-companies seeking to invest in long-term projects with high near-term uncertainty, that may not be easily financed with debt, since managers will be insulated from short-term share price declines while implementing the necessary long-term investment in product innovation and long product-cycles. With companies that display such attributes, it becomes easier to contemplate the notional benefits that dual-class structure can provide, and the possibility for those benefits to outweigh the notional detriments stemming from the inherent incentives to extract private benefits to the detriment of outside stockholders. However, with, for instance, a mature manufacturing company with observable assets, little in the way of product innovation, and where firm-specific skills do not need to be developed by employees, it is harder to discern the potential benefits that dual-class structure can provide, making it more likely that the structure has been adopted by the controller to primarily extract pernicious private benefits. Consequently, it is possible that dual-class structure is beneficial for certain types of firms and detrimental for other types of firms. On that basis, empirical studies that group all dual-class firms together without sub-sampling will not be picking-up the nuances related to the diversity of firms, and will, instead, be making sweeping statements as to the virtues or otherwise of dual-class structure. Even with substantial matching criteria, a study will not be sufficiently granular if each matched sample is then simply aggregated.

As noted in discussing the empirical studies in Parts II to IV of this article, a developing area of empiricism in this field is to sub-sample dualclass firms, and studies of this type can provide valuable testimony. Firm valuation studies have suggested that for high-growth firms ${ }^{225}$ young firms, ${ }^{226}$ and firms that have only recently conducted $\mathrm{IPOs}^{227}$ the correlation pattern is reversed, and dual-class structure becomes correlated with positive firm values. In Part V of this article, it was postulated that the market over-discounts dual-class firms since dual-class firm valuations are lower than, yet buy-and-hold stock returns and operating performances are higher than, OSOV firms. That inference could be challenged if subsampling shows that certain dual-class firms are valued higher than OSOV firms, and, in fact, the market may be sufficiently sophisticated to recognize whether or not a dual-class firm is of a type where the benefits of the structure are likely to outweigh the detriments. However, the fact that, when grouping all dual-class firms together, on average, dual-class firm values are generally lower than matched OSOV firms, and, on average, buy-and-hold stock returns and operating performances are generally

225. Jordan et al., supra note 84 , at 317.

226. Kim \& Michaely, supra note 85 , at 1.

227. Cremers et al., supra note 53, at 5. 
higher for dual-class firms than matched OSOV firms, suggests that the market is not particularly good at identifying all those firms for which the benefits will outweigh the detriments. Alternatively or additionally, for those dual-class firms that are valued higher than OSOV firms, the market may still be applying a discount but the market's presumption of substantial complementary benefits to shareholder-wealth generated by such firms considerably exceeds the discount applied. In relation to the second alternative/additional explanation, limited empirical evidence does indeed indicate that even those firms that are valued higher by the market are still being discounted when compared to their operating performance, but with the discount not sufficient to mask the positive effect of high operating performance on firm value. ${ }^{228}$

A potentially more critical aspect of the empirical evidence on subsampled dual-class firms lies in those that indicate differing operating performance levels between types of dual-class firms. Certain of the studies showed that firms associated with the controller diversifying wealth, ${ }^{229}$ or that issued further equity, ${ }^{230}$ after conversion of capital structure into dual-class stock, drive operating outperformance compared to OSOV firms. Those same studies, when grouping all dual-class firms in the sample together, either showed that dual-class firms performed better than OSOV $^{231}$ firms or at the same level as OSOV firms ${ }^{232}$ - nevertheless, they seem to show that operating performance is even better for certain types of dual-class firms. More concerning is the study by Kim and Michaely (2018) which showed that for mature (more than or equal to twelve years-old) dual-class firms, operating performance was worse than mature OSOV firms, and for young (less than twelve years-old) dual-class firms, operating performance was better than young OSOV firms. ${ }^{233}$ The time dimension, which will also relate to firm growth-profile, is an area ripe for further research. ${ }^{234}$ If further empirical evidence can corroborate

228. See, e.g., Chemmanur et al., supra note 85, at 684 (showing that dual-class firms with high quality management showed positive abnormal returns notwithstanding that they also showed higher firm valuations than OSOV-firms); BÖHMER ET AL., supra note 66 (showing, again, that dual-class firms displayed higher firm valuations, and higher buy-and-hold stock returns, than OSOV firms). In Switzerland, Nüesch found that the positive correlation between dual-class structure for firms requiring external finance and firm performance was much greater for ROA than Tobin's Q. Nüesch, supra note 123, at 542.

229. Bauguess et al., supra note 61 , at 1246.

230. Dimitrov \& Jain, supra note 37, at 347; Lehn et al., supra note 139, at 559.

231. Lehn et al., supra note 139, at 574.

232. Dimitrov \& Jain, supra note 37, at 1251; Bauguess et al., supra note 61, at 31 .

233. Kim \& Michaely, supra note 85 , at 5.

234. In one study, the SEC compared post-IPO firm values of dual-class firms with 
that the excess operating performance of dual-class firms tends to decline over time to the extent that it is less than equivalent OSOV firms, lower firm valuations for dual-class firms could be justified in certain circumstances, such as where it is clear that the operating performance of the relevant dual-class firm will inevitably fall to a level lower than similar OSOV firms. Better empirical evidence of this nature can guide more focused regulatory interventions, as will be discussed further in "Policy Implications" below, but for the time being, based upon the empirical evidence currently existing, overall, and on average, investors are discounting dual-class firms to a degree that is not justified by the average operating performances of those firms, resulting in higher buy-and-hold stock returns for such investors. Even if it were found that dual-class structure is only beneficial for outside stockholders for a minority of firmtypes, the fact that, overall, dual-class structure correlates with higher operating performance would suggest that those companies for which the structure is beneficial outperform OSOV firms to a greater degree than the other dual-class firms underperform OSOV firms. In such a case, until more robust granular empirical evidence is obtained as to exactly the types of firms for which dual-class structure is beneficial to operating performance, caution should be exercised prior to deterring the adoption of dual-class stock, since it could overall harm shareholder-wealth maximization when viewed across the equity market as a whole. As elaborated by Bessembinder (2018), ${ }^{235}$ the net gain for the U.S. stock market between 1926 and 2016 can be attributed to only four percent of listed companies. Extrapolating from such evidence, in the context of sunset clauses, Sharfman (2019) noted the importance of ensuring that the best performing firms are able to adopt the governance structures that give them the optimum opportunities to succeed - "inhibiting one company

mechanisms that converted them into OSOV after specific periods of time (time-dependent sunset clauses - see infra note 259 , and accompanying text), with firm values of perpetual dual-class firms. In preliminary results, the former were found to outperform the latter from two years after IPO. Robert J. Jackson Jr., Comm'r, U.S. Sec. \& Exch. Comm'n, Perpetual Dual-Class Stock: The Case Against Corporate Royalty (Feb. 15, 2018). However, there are numerous reasons to explain the results that do not necessarily relate to the governance of those firms, Bernard S. Sharfman, On Governance: SEC Commissioner Robert Jackson and Perpetual Dual Class Shares, The CONFEREnce BoARD (Apr. 10, 2018), https:/www.conference-board.org/blog/environmental-social-governance/Robert-JacksonPerpetual-Dual-Class-Shares [https://perma.cc/5EMB-K9Z7], and it would be useful for further research to assess the contrast in operating performance between sunset and nonsunset dual-class firms over extended periods of time. A sufficiently robust sample set may not, though, be available yet.

235. Hendrik Bessembinder, Do Stocks Outperform Treasury Bills?, 129 J. FIN. Econ. 440, 456 (2018). 
from becoming the next Alphabet or Facebook, it is one company too many.",236

\section{B. Controller Identity}

Beyond the diversity of firm types, another consideration is what Holderness labelled the, "richness of blockholders". ${ }^{237}$ The nature of the controller will have significant bearing on whether dual-class structure will be utilized in a manner that benefits or harms outside stockholders. Taking tech-companies as an example, in the hands of a visionary and talented founder, dual-class structure can support the idiosyncratic vision ${ }^{238}$ of the founder which requires investment in $\mathrm{R} \& \mathrm{D}$ and product-cycles that may reduce profits in the short-term but create substantial, although possibly initially unobservable to the market, long-term profits. However, in the hands of a founder with little perspicacious ability, dual-class structure may shelter a failing long-term vision, or, worse, enable the controller to extract substantial private benefits to the detriment of outside stockholders without any compensatory increase in long-term profits.

The existing empirical evidence is instructive to a degree. For example, it has been found that better operating performance by companies that have implemented antitakeover devices (including dual-class stock) are driven by those companies with high-quality management. ${ }^{239}$ Additionally, there is some indication that the merits of dual-class structure may lie in it promoting the listing of more founder-owned companies which outperform non-founder-owned companies. ${ }^{240}$ If the controller is not a founder, there may be lesser prevalence of the theoretical benefits of dual-class structure. Equally, controllers that are corporations may have different motivations and incentives as compared to individuals, as will blockholders of enhanced-voting stock that do not have majority control of the corporation, or who do not participate in management. ${ }^{241}$

236. Sharfman, The Undesirability of Mandatory Time-Based Sunsets in Dual Class Share Structures: A Reply to Bebchuk and Kastiel, supra note 8, at 10.

237. Clifford Holderness, A Survey of Blockholders and Corporate Control, FRBNY ECON. Policy ReV. 51, 60 (2003).

238. The term "idiosyncratic vision" has been used in the literature to describe the unique talents and vision of a founder to pursue a successful business strategy, the long-term success of which is not easily discernible by those without the same abilities. See, e.g., Goshen \& Hamdani, supra note 53, at 577.

239. Chemmanur et al., supra note 85.

240. Supra notes 109-10, and accompanying text.

241. However, it is rare for controllers not to be individuals, not to possess majority or effective control, and not to participate in management. Supra notes 46-48. 
Further research that identifies the extent to which the identity of the controller affects the probity of dual-class firms would provide a valuable contribution to policy discussion. The lack of controller profiling has been labelled the, "biggest missing factor affecting the probability of tunneling". ${ }^{42}$ However, whereas studies can control for the diversity of firm-types, it is far more challenging to control for the diversity of controllers. Some characteristics, such as founder-controlled versus corporate-controlled firms, are easy to identify, but others, such as the nature, characteristics and intents of the controller are difficult to identify, and may not be observable. ${ }^{243}$ Even identifying whether a controller is a high- or low-quality manager is not simple. ${ }^{244}$ Therefore, even though further empirical research in this sphere may be helpful, ${ }^{245}$ it is unlikely that clear brightline divisions will be proved. As remarked by Smart and Zutter (2003): "Discerning which managers are entrenched to capture private control benefits and which are entrenched in the interests of shareholders challenges the empiricist." 246

In summary, the type of firm and nature of the controller will have a bearing on whether in practice the theoretical benefits or detriments of dual-class structure dominate within a specific firm. Further empirical research will serve policy considerations well, but it may not be possible to fine-tune research to a level that can clearly determine which firms should or should not, from the perspective of outside investors, adopt dual-class structure. Even without more granular dual-class stock empirical evidence on the qualities of firms and controllers, the market possibly organically protects itself, at the time of IPO, from the most egregious types of dualclass firms and dual-class firm controllers, on the basis that investors will simply refuse to invest in dual-class corporations that are more obviously

242. Christopher Chen et al, Board Independence as a Panacea to Tunneling? An Empirical Study of Related-Party Transactions in Hong Kong and Singapore' 15 J. EMPIR. LED. STUD. 987, 1017 (2018). "Tunneling" is a euphemism for the extraction of profits and assets by a controller for its benefit (i.e. private benefit extraction). Simon Johnson et al, Tunneling, 90 AEA PAPERS AND PROCEEDINGs 22, 22 (2000).

243. Lynne Dallas \& Jordan Barry, Long-Term Shareholders and Time-Phased Voting, 40 DJCL 541, 589 (2016).

244. Chemmanur et al. used a number of proxies for the quality of management (see supra note 114), but significant assumptions need to be made as to the accuracy of such proxies, and it is certainly not clear that managers satisfying the relevant proxies are definitively highquality managers.

245. An appeal for such evidence was made as far back as 1996 in BÖHMER ET AL., supra note 66 , at 116 .

246. Smart \& Zutter, supra note 158; Dov Solomon, The Importance of Inferior Voting Rights in Dual-Class Firms, 2019 BYU L. REV. 533, 543 (2019) expressed that it is impossible to discern whether a founder will utilize its superior skills to benefit all shareholders, or, instead, to extract controller benefits. 
geared toward prioritizing the extraction of private benefits detrimental to outside stockholders over the benefits that the structure can engender. Without institutional investor support, given the dominance of institutional investors in the market, ${ }^{247}$ it is likely that the relevant flotation will be abandoned. For example, the decision by The We Company to abandon its IPO was partly based upon an underlying distrust of the founder's abilities, and soon after the abandonment, it was announced that the founder would resign as CEO and potentially relinquish his enhanced-voting shares. ${ }^{248}$ Similarly, Uber Technologies Inc. did not countenance a listing until Travis Kalanick, whose behavior had been very publicly denounced, had been removed as CEO, and the corporation's dual-class structure converted to OSOV. ${ }^{249}$ Such filtering of firms, although occurring on a broad basis without the granular considerations alluded to above, may be an explanation for dual-class firms as a whole showing better operating performance on average than OSOV firms. The market has filtered out the types of firms and controllers that are most likely to abuse dual-class structure to expropriate outside stockholders. Until more granular evidence is procured, policy considerations should be made based upon the overall empirical evidence pertaining to dual-class firms which shows that such firms perform at least as well as OSOV firms in terms of operating performance, and do not harm outside stockholders in terms of returns.

\section{POLICY IMPLICATIONS}

In recent years, dual-class stock has attracted much opprobrium mainly based upon the perception that the structure is harmful to outside

stockholders. Lawmakers have criticized the concept of dual-class stock, ${ }^{250}$ and institutional shareholders have lobbied the exchanges and private-

247. The Securities Industry and Financial Markets Association, supra note 100, at 60, showed that, in 2018, institutions owned $62.4 \%$, and "households" owned $37.6 \%$, of U.S.equities. The figure for "households" may even be overstated by including holdings by nonprofit organizations, and presumably certain indirect retail ownership through institutional funds, and the percentage of U.S.-equities held directly by institutions may be higher. Raymond Chan \& John Ho, Should Listed Companies Be Allowed to Adopt Dual-Class Share Structure in Hong Kong?, 43 COMM. L. World REV. 155, 175 (2014); Charles McGrath, 80\% of Equity Market Cap Held by Institutions, PEnsions \& Investments (Apr. 25, 2017).

248. A. Edgecliffe-Johnson \& E. Platt, WeWork Founder Trades Voting Power to Back SoftBank Rescue, Fin. Times (Oct. 21, 2019).

249. M. Isaac, Uber Sells Stake to SoftBank Valuing Ride-Hailing Giant at \$48 Billion, NY TIMES (Dec. 28, 2017).

250. On June 5, 2013, Senator Elizabeth Warren (D-MA) sent a letter to the vicepresidents of the NYSE and NASDAQ urging them to consider rules mandating OSOV. Letter from Elizabeth Warren to John Carey and Edward Knight (June 5, 2013). 
sector indices to implement curbs on the use of dual-class structure, ${ }^{251}$ leading to the S\&P Dow Jones, in 2017, declaring that it will not include any new dual-class entrants to its S\&P Composite 1500 indices. ${ }^{252}$ The rationale behind the decision was that an index fund that is required to track the relevant index should not be forced to invest in dual-class stock that could be harmful to the fund's interests. ${ }^{253}$ Caution, though, should be exercised by indices, and, indeed, exchanges and regulators, in their approach to dual-class firms based upon such a premise. Concerns regarding the propensity for dual-class firms to be injurious to shareholder wealth-maximization are not borne out by the empirical evidence. ${ }^{254}$ Investors protect themselves from the risks apparently inherent in dualclass structure by discounting the inferior-voting stock of such firms. In terms of stock returns, investors in dual-class stock are not harmed as compared to investing in similar OSOV firms, since they earn at least as good returns as investments in OSOV firms, and there is good evidence that they earn much better returns from dual-class firm investments. Proscribing dual-class firms from the indices excludes passive investment funds, and, by extension, individuals investing in many pension plans, insurance products and index trackers, from sharing in the disproportionate returns offered by dual-class stock on a diversified basis. The ideological distaste of dual-class stock by institutional investors may, counterintuitively, be harming them, and exchanges and regulators in

251. Sharfman, A Private Ordering Defense of a Company's Right to Use Dual Class Share Structures in IPOs, supra note 8, at 3; D. Lund, Nonvoting Shares and Efficient Corporate Governance, 71 StAN. LAW REV. 687, 709 (2019); See infra note 259.

252. S\&P Dow Jones Indices, S\&P Dow Jones Indices Announces Decision on MultiClass Shares and Voting Rights, (July 31, 2017). Since 2017, FTSE Russell has also omitted new dual-class stock entrants from its indices unless at least five percent of the voting rights are freely available to the public. FTSE Russell, Voting Rights Consultation - Next Steps, (July 2017) https://www.spice-indices.com/idpfiles/spice-assets/resources/public/documents/ 561162_spdjimulti-classsharesandvotingrulesannouncement7.31.17.pdf?force_download=tr ue [https://perma.cc/A47Y-3B97]. MSCI declined to omit dual-class firms from its regular indices; instead, it launched new benchmark indices that only comprise OSOV firms, or weight firms for voting rights. MSCI Press Release, MSCI Will Retain the MSCI Global Investable Market Indexes Unchanged and Launch a New Index Series Reflecting the Preferences of Investors on Unequal Voting Structures, (Oct. 30, 2018) https://www.msci.com/documents/10199/0b548379-fbe7-71c7-b392-7140b2215cc9 [https:// perma.cc/DE42-GP5B]; MSCI, MSCI Voting Rights-Adjusted Indexes Methodology, (Mar. 2019) https://www.msci.com/eqb/methodology/meth_docs/MSCI_Voting_Rights_Adjusted _Indexes_Methodology_Mar2019.pdf [https://perma.cc/6Y78-UQM5].

253. Index funds are passive investors that systematically track specific indices, such as the S\&P 500. For a more detailed description of index funds, see Lucian Bebchuk \& Scott Hirst, Index Funds and the Future of Corporate Governance: Theory, Evidence, and Policy, 2019 ColuM. L. REv. 2029, (2019).

254. Anderson et al., supra note 46 , at 8 . 
developing policy should not be overly influenced by their concerns toward dual-class firms in the face of contrary empirical evidence.

The tone of the discussion should morph. Operating performance studies trend toward a finding that dual-class firms outperform similar OSOV firms, and certainly do not show poorer performance than OSOV firms. Dual-class firm management teams are not, on the whole, managing their firms less assiduously than OSOV firms nor excessively expropriating outside stockholders. ${ }^{255}$ Since the opportunities for post-profits private benefit extraction (without a commensurate decrease in operating performance results over, as assessed by most operating performance studies, multiple years) are limited in high investor protection jurisdictions such as the U.S., it would appear that the lower firm values attributed to dual-class firms are largely unjustified. The question to be asked should shift away from whether the market is harmed by dual-class firms to whether the market discounts dual-class firms too much? Although for certain types of dual-class firms the difference in firm value compared to OSOV firms is attenuated (and some are even valued at a premium to OSOV firms), it is still possible that a discount is being applied (with the premium attached to those dual-class firms not fully reflecting the substantially better operating performance of those firms). Even if a discount is not being applied to certain types of firms, and the market is sufficiently sophisticated to recognize that dual-class structure is likely to be a benefit to those types of firms, clearly the market does not yet identify all "good" dual-class firms, since taking all dual-class firms together, their firm values are on average worse, while operating performance and stock returns are on average better, than similar OSOV firms. The market assumes it is investing in lemons, while dual-class firms continue to make lemonade. ${ }^{256}$ As a consequence, the cost of capital for dual-class firms is disproportionately higher than it should be, and the possibility remains that some "good" potential controllers of dual-class firms will eschew flotations if cost of capital is high. Additionally, if a firm does list with dual-class structure but subsequently requires further substantial equity funding for growth, continued high costs of capital could result in the controller unifying the capital structure to OSOV at a time when it may be more beneficial to long-term success to continue with dual-class structure. Policy considerations should turn toward determining how to reduce the cost of capital for dual-class issuers rather than how to deter dual-class issuers from listing in the first place.

255. Supra notes $187-88$.

256. See supra notes 222-24, and accompanying text (discussing the variation of the "market for lemons" theme above). 
Although outside the scope of this article, cost of capital can be reduced for dual-class firms by restricting the use of the structure to those types of firms and controllers that are more likely to prioritize the benefits of dual-class structure to outside stockholders rather than the detriments, by introducing constraints around the ability of controllers to extract the most egregious varieties of private benefits, and/or by formulating mechanisms that cause dual-class structure to convert into OSOV upon the emergence of indicators that the structure has become overall detrimental to outside stockholders. Such an approach would give investors more comfort that they are not participating in the lemons-trade, and therefore should encourage a reduction across the board of the discounts being applied to dual-class firms. In relation to restricting dual-class structure to particular types of firms and controllers, jurisdictions such as Hong Kong, Singapore and Shanghai already require dual-class issuers to conform to specific preconceived attributes. ${ }^{257}$ However, it is submitted that the U.S. empirical evidence is not yet sufficiently robust or broad to discern exactly for which firms dual-class structure should be permitted. Further empirical research may assist, and would be welcome, although, as discussed in this article, a degree of skepticism can be directed at whether it is possible to develop brightline rules. In any event, the market may be organically filtering-out "bad" dual-class firms at the IPO stage. This may explain, in part, the proliferation of tech-companies adopting dual-class structure - the structure can engender substantive operating benefits for tech-companies and the market tolerates their listings by recognizing the potential for those benefits to manifest themselves in higher stock returns. In relation to developing constraints on dual-class firms once they have been listed, it is further submitted that such constraints must be carefully constructed, since they must not be so astringent that they deter the controllers of dual-class corporations listing in the first place.

The worm may have already started to turn. Rather than lobbying for an outright prohibition of dual-class stock, even institutional investor behemoths such as Blackrock, Vanguard and State Street now acknowledge that dual-class structure can be beneficial for at least a part of a firm's life-

257. Hong Kong only permits "innovative" companies to list with dual-class stock, (HKEX Guidance Letter HKEX-GL93-18, Suitability for Listing with a WVR Structure, at para. 4.2 (Apr. 2018)), while Singapore will assess the extent to which dual-class structure will benefit the relevant company based upon its business model prior to admitting a company to list with dual-class structure. SGX, Consultation Paper: Proposed Listing Framework for Dual Class Share Structures, at 2 (Mar. 28, 2018). Shanghai only permits dual-class stock on a specific board dedicated to science and technology companies. John Kong Shan Ho, Examining the Viability to Allow Dual-Class Share Structure Companies to List in the Financial Market of the People's Republic of China: Lessons and Experiences From Hong Kong 1, 26 (2019). 
cycle, ${ }^{258}$ and the Council for Institutional Investors, a representative body for institutional investors, has lobbied the NYSE to mandate that dual-class firms implement mechanisms that cause the structure to convert into OSOV upon a period of no more than seven-years post-IPO - so called "timedependent sunset clauses". ${ }^{259}$ In relation to time-dependent sunset clauses, this author advocates that more focused sunset provisions be utilized instead. Although some empirical evidence suggests that dual-class stock is more beneficial for companies during their growth-phases, time is merely a proxy for other changes that occur throughout the life-cycle of a dualclass firm, and any universally selected time period after which all dualclass firms must convert into OSOV will be arbitrarily determined. ${ }^{260} \mathrm{~A}$ shrewder approach would be to implement mechanisms that convert dualclass structure into OSOV upon specific events occurring, combined with provisions that limit the ability of controllers to extract the most egregious types of private benefits while dual-class structure is extant. In particular, given that empirical evidence suggests that performance may be driven by founder-control, ${ }^{261}$ and, pertinently, investors in dual-class firms are likely investing based upon the faith they have in the vision and skills of the controller, serious consideration should be given to mandating transferdriven sunset provisions such that transfers of enhanced-voting stock from the original holders will result in those specific shares converting into OSOV. ${ }^{262}$ Developing the relevant inferior-voting shareholder protections is a matter for future study.

\section{CONCLUSION}

The internecine dual-class stock battle between founders and investors mimics that between the Autobots and Decepticons of Transformers lore. ${ }^{263}$ However, like those robots, when considering the empirical evidence on

258. BlackRock, Open Letter Regarding Consultation on the Treatment of Unequal Voting Structures in the MSCI Equity Indexes, (Apr. 19, 2018) https://www.blackrock.com/co rporate/literature/publication/open-letter-treatment-of-unequal-voting-structures-msci-equit y-indexes-041918.pdf; [https://perma.cc/5JD2-YBWN]; Scott Hirst \& Kobi Kastiel, Corporate Governance by Index Exclusion, 99 B.U. L. REV. 1229, 1234 (2019).

259. CII Letter to E. King, Chief Regulatory Officer, International Exchange Inc. (Oct. 24, 2018) https://www.cii.org/files/issues_and_advocacy/correspondence/2018/20181024 NYSE Petition on Multiclass Sunsets FINAL.pdf [https://perma.cc/Z3ML-ECV8].

260. Fisch \& Solomon, supra note 137, at 17; Reddy, supra note 8, at 342; Sharfman, The Undesirability of Mandatory Time-Based Sunsets in Dual Class Share Structures: A Reply to Bebchuk and Kastiel, supra note 8; Moore, supra note 8, at 145.

261. See text accompanying supra notes 106-12.

262. See supra note 111 (discussing conversion of shares through transfer-driven sunset provision).

263. See supra note 1. 
dual-class stock, there is "more than meets the eye." Contrary to the prevailing perception that dual-class stock is harmful to outside stockholders, dual-class firms are at least as profitable as OSOV firms, and investors in those firms earn returns at least comparable to those earned by investors in similar OSOV firms. In fact, the majority of the empirical evidence indicates, if anything, that dual-class firms perform, on the basis of accounting measures, better than OSOV firms, which is reflected by greater returns accruing to portfolios of dual-class firms than portfolios of similar OSOV firms. In contrast, and flying in the face of operating performance and stock return results, it would appear that, on average, dual-class firms are valued less than OSOV firms. The riddle presented by that conflict can be solved by an acknowledgment that the market is discounting dual-class stock to protect itself against the potential that the detriments of the structure will outweigh the benefits, but, in fact, such a negative balance does not, in general, emerge. Policy-makers should take heed of the evidence that suggests that outside stockholders are not harmed by dual-class stock - they invest in dual-class stock at a price which organically gives them protection against being expropriated in the future, and, based upon the trends in the empirical evidence, apparently discount dual-class stock too much. Policy considerations should evolve from attempting to deter the use of dual-class stock to attempting to reduce the cost of capital for dual-class issuers through introducing mechanisms that give comfort to outside stockholders by moderating the risks of their expropriation. Although the tension between founders and public investors may never fully be satiated, ${ }^{264}$ in the world of dual-class stock, we may, finally, be on the verge of peace.

264. As a recent example, see the Business Roundtable, Statement on the Purpose of a Corporation, (Aug. 2019) https://opportunity.businessroundtable.org/ourcommitment/ [https: //perma.cc/DZ8T-CBS6] (stating corporate purpose); see also CII, Council of Institutional Investors Responds to Business Roundtable Statement on Corporate Purpose, (Aug. 19, 2019) https://www.cii.org/aug19_brt_response [https://perma.cc/96VK-UCK3] (responding to Business Roundtable's statement). 